\title{
Contemporaneous Peer Effects, Career Age and the Industry Involvement of Academics in Biotechnology
}

\author{
Aschhoff, Birgit; Grimpe, Christoph
}

Document Version

Accepted author manuscript

Published in:

Research Policy

DOI:

10.1016/j.respol.2013.11.002

Publication date:

2014

License

CC BY-NC-ND

Citation for published version (APA):

Aschhoff, B., \& Grimpe, C. (2014). Contemporaneous Peer Effects, Career Age and the Industry Involvement of Academics in Biotechnology. Research Policy, 43(2), 367-381. https://doi.org/10.1016/j.respol.2013.11.002

Link to publication in CBS Research Portal

\section{General rights}

Copyright and moral rights for the publications made accessible in the public portal are retained by the authors and/or other copyright owners and it is a condition of accessing publications that users recognise and abide by the legal requirements associated with these rights.

\section{Take down policy}

If you believe that this document breaches copyright please contact us (research.lib@cbs.dk) providing details, and we will remove access to the work immediately and investigate your claim.

Download date: 26. Apr. 2023 


\title{
Contemporaneous Peer Effects, Career Age and the Industry Involvement of Academics in Biotechnology
}

\section{Birgit Aschhoff and Christoph Grimpe}

\author{
Journal article (Post print version) \\ This article was originally published in Research Policy, Vol. 43, Issue 2, Pages 367- \\ 381. First published online December 14, 2013. \\ DOI: 10.1016/j.respol.2013.11.002
}

Uploaded to Research@CBS: March २०16

(C) 2016. This manuscript version is made available under the CC-BY-NC-ND 4.0 license http://creativecommons.org/licenses/by-nc-nd/4.0/ 


\title{
Contemporaneous peer effects, career age and the industry involvement of academics in biotechnology
}

\author{
Birgit Aschhoff ${ }^{\mathrm{a}, *}$ and Christoph Grimpe ${ }^{\mathrm{b}}$ \\ a) Centre for European Economic Research (ZEW), L7. 1, Mannheim, Germany \\ b) Copenhagen Business School, Kilevej 14A, Frederiksberg, Denmark \\ Published in Research Policy, Vol. 43, 367-381. The final version can be found at \\ http://www.sciencedirect.com/science/article/pii/S0048733313002060
}

\begin{abstract}
This study explores the role of contemporaneous peer effects in driving an academic's involvement with industry. Specifically, we examine the influence of workplace peers and personal collaborators and how these effects are moderated by the career age of the scientist. Moreover, we look at situations in which both types of social influence are incongruent and the academic is faced with "dissonance". Based on survey data of 355 German academics in the field of biotechnology and publication data from the Science Citation Index Expanded (SCIE), we find that the scientist's involvement with industry increases with the orientation of the scientist's department towards industry ("localized peer effect”). This effect turns out to be moderated by the scientist's age, such that the localized peer effect decreases with age and finally turns negative for very senior scientists. Moreover, we find that a scientist's involvement increases with the industry orientation of the scientist's co-authors ("personal peer effect”), irrespective of the scientist’s age. In case both types of social influence are incongruent, younger scientists will revert to localized norms while more experienced scientists will orient themselves more towards their personal collaborators.
\end{abstract}

Keywords: university-industry interaction, peer effects, imprinting, biotechnology

* Corresponding author. Tel.: +49 6211235182.

E-mail addresses: aschhoff@zew.de (B. Aschhoff),cg.ino@cbs.dk (C. Grimpe). 


\section{Introduction}

How does social interaction influence an academic's decision to become entrepreneurial and to collaborate with industry? How is the academic's behavior influenced by intersecting types of social interaction? Does the academic's age attenuate or amplify these effects? A growing body of literature has begun to study questions on the effects of individuals in the environment of an academic in shaping his or her engagement in commercial activities (e.g., Louis et al., 1989; Stuart and Ding, 2006; Bercovitz and Feldman, 2008; Kacperczyk, 2013). One reason for such peer effects to occur has been described as "imprinting", defined as a process in which, during a certain period of time, an individual develops persistent characteristics that mirror central features of the environment (Marquis and Tilcsik, 2013). The environment, in turn, "is not a homogeneous setting but a varied, ndimensional space in which a set of economic, technological, and institutional conditions, as well as the influence of particular individuals, coexist and jointly constitute the stamp of the period" (Marquis and Tilcsik, 2013: 227).

Several prior studies have addressed the role of workplace peers in imprinting an academic's behavior. Among them, Stuart and Ding (2006) find that scientists with co-authors who have become academic entrepreneurs are more likely to become commercially active themselves. Similarly, Kacperczyk (2013) shows that past entrepreneurial activity of university peers influences individual rates of entrepreneurship. Bercovitz and Feldman (2008) show that scientists are more likely to disclose their inventions if they observe technology transfer activities among their local peers. Azoulay et al. (2009) find early career experiences to have a substantial impact on academics' careers. One line of argument suggests that such effects are due to better information or resources that the scientist's social environment might provide (e.g., Sorensen and Audia, 2000). Another line of argument focuses on reference groups and social norms to explain individual behavior (e.g., Louis et al., 1989; Kenney and Goe, 2004; Bercovitz and Feldman, 2008). In a Mertonian view, universities are seen as repositories for the norms of open science, characterized as communalism, universalism, disinterestedness, and organized skepticism (Merton, 1973). Producing and diffusing scientifically valuable knowledge to realize an economic return thus implies a departure from the traditional 
mission and priority of academia (Dasgupta and David, 1994). In this regard, workplace peers may influence the informational and normative environment that exerts an effect on the decision to become commercially active.

Despite these insights, relatively little empirical attention has been devoted to multiple coexisting peer effects (Marquis and Tilcsik, 2013). Bercovitz and Feldman (2008) find that an academic's training norms may be incongruent with the localized social norms in the current work environment in which case the individual will conform to the local norms. However, it is unclear how different contemporaneous imprints interact in shaping an academic's involvement with industry. Moreover, we know little about the breadth and prevalence of different ways to get involved with industry as a result of peer effects. Prior literature is largely confined to studying invention disclosures or academic entrepreneurship (e.g., Stuart and Ding, 2006; Bercovitz and Feldman, 2008), although industry-science interaction may be multifaceted (D'Este and Patel, 2007).

In this paper, we draw a distinction between "localized" and "personal" peer effects on academics' involvement with industry to shed light on two different types of contemporaneous peer effects in a university environment. We suggest that a scientist's involvement with industry will increase with the orientation of the scientist's department towards industry, which we call a localized peer effect. Moreover, we expect a scientist's involvement with industry to increase with the industry orientation of his or her personal collaborators, an effect we call a personal peer effect. Besides our interest in whether these effects take the same or different directions, we seek to study their interaction and specifically a situation in which they are incongruent and hence "dissonant”. Prior literature has also widely acknowledged the importance of age on an individual's susceptibility to imprinting (Marquis and Tilcsik, 2013). We expect both the localized and the personal peer effect to be stronger the more recent the vintage of the scientist's $\mathrm{PhD}$, suggesting that imprinting takes place in the early stages of a scientist's academic career. Moreover, we hypothesize that the effects of dissonance will be different between young and experienced scientists. With respect to the dependent variable, we follow Bozeman and Gaughan (2007) and consider a broader set of industry-science interactions by using an industry involvement index that comprises five different channels of knowledge and technology exchange. 
Our empirical analysis is based on a sample of 355 academic scientists working in the field of biotechnology in Germany who were surveyed in 2010. In fact, one of the industries that is particularly knowledge-driven and close to scientific research is the biotechnology industry. Technology for new products, methods and services frequently emerges from scientific institutions or in collaboration between firms and such institutions (e.g., Audretsch and Stephan, 1996; Zucker et al., 2002). Involving researchers from academia tends to be more important in biotechnology than in other sectors (Higgins et al., 2008). Germany has a lively and growing biotechnology scene, involving about 540 dedicated biotech companies as well as about 200 universities and public research institutions that carry out biotechnological research (BIOCOM, 2011).

We aim to contribute to the literature in three ways. First, we extend existing studies in the field by focusing on different contemporaneous peer effects while accounting for other environmental conditions and individual characteristics that may explain an academic's industry involvement. We distinguish between the effects that stem from localized and personal peers, allowing us to examine the relative impact of both as well as their interaction. Specifically, we shed light on congruent versus dissonant peer effects, an understudied, yet important area of research on peer effects in industryscience interaction. Second, we identify the researcher's career age as an important boundary condition for a researcher's susceptibility to imprinting. While the career age may directly influence the strength of peer effects, it is important to understand its role when peer effects are congruent or dissonant in order to derive implications for the management of science organizations and to extend existing models of imprinting through social interaction (Marquis and Tilcsik, 2013). Third, we extend prior literature on peer effects and industry involvement that has limited the researcher's commercial activity to a specific type such as the disclosure of an invention or patenting. University faculty may engage in a wide variety of interactions with industry of which patenting may only be one channel. D'Este and Patel (2007) have argued that accounting for the variety of industry-science interaction is a crucial complement to more traditional measures used in prior literature. In that respect, our research is positioned to further contribute to the body of literature that investigates the factors driving academics to depart from the traditional mission of the university and to engage with industry (e.g., Meyer-Krahmer and Schmoch, 1998; Link et al., 2007). 
The remainder of the paper is organized as follows. The next section provides a literature background on academic involvement with industry and derives hypotheses. The data, variables and estimation methods are discussed in section 3. Section 4 presents the results and several robustness tests. A discussion and concluding remarks appear in section 5.

\section{Peer effects and academics' involvement with industry}

\subsection{Literature background}

While research on peer effects motivating academics to engage with industry is a relatively small but growing area of interest, there is a rich body of literature investigating the nexus between public science and industry. Hence, the purpose of this section is to position our research in the broader context of the literature on industry-science interaction and to outline those strands in the literature particularly relevant for our research. In fact, it has almost become conventional wisdom that knowledge produced in the public sector constitutes an important ingredient of economic growth and technological progress (Jaffe, 1989; Adams, 1990). Close links to academic research have been shown to be beneficial for the innovation performance of firms (Cockburn and Henderson, 1998; Belderbos et al., 2004; Arvanitis et al., 2008) because of the novelty and sophistication of the knowledge that universities create (Link et al., 2007). Moreover, universities offer access to basic research, talented people and complementary resources and allow the firm to explore new technological opportunities (Dasgupta and David, 1994; Sorensen and Fleming, 2004). Scientific knowledge does not, however, automatically spill over to industry. Knowledge and technology transfer relies on the engagement of the individual academic (Louis et al., 1989; Bercovitz and Feldman, 2007) and is thus dependent on the individual's decision to actively participate in industry-science activities through a variety of channels that can be either formal or informal. Formal involvement is typically based on a patent to be sold or licensed out (Bozeman, 2000; Thursby and Thursby, 2002) or collaboration in R\&D (Laursen et al., 2011), while informal channels of interaction might involve industrial consulting (Jensen et al., 2010), joint publication of research results with industry personnel or informal contacts (Link et al., 2007; Grimpe and Fier, 2010). 
The complexity that comes with the exchange of novel and sophisticated knowledge between academia and industry suggests several factors besides peer effects to play a role in motivating academics to engage with industry. In the following, we will therefore revert to the general model of imprinting developed by Marquis and Tilcsik (2013) that we believe is helpful in structuring and assessing the different factors influencing industry-science interaction. The model focuses on individuals as the entities bearing the imprint and explains a focal entity's reflection of certain characteristics as imprints from the environment and other entities during a sensitive period. It suggests that the entity bearing the imprint may move through periods during which it may not be sensitive to those imprints and that it may itself become a source of "secondhand" imprints on other entities. A key assumption of the model is a certain level of persistence of the imprint over time that allows the imprint to be actually identified and traced back to its source. As a result of the model, the characteristics an entity shows may stem from different layers of imprints that interact in an ex-ante indeterminate way.

A first central element of the model is thus the entity bearing the imprint which in our context is the individual scientist. In fact, prior literature has focused extensively on why individual scientists are involved with industry. One of the conceptual lenses adopted in this literature is the scientific and technical human capital approach, which recognizes scientific and technical human capital as “individual endowments”, tacit and craft knowledge as well as social contacts and networks (e.g., Bozeman and Corley, 2004; Ponomariov and Boardman, 2010). Scientists accumulate scientific and technical human capital with their career age, scientific productivity, hierarchical position and previous successful collaboration with industry (Belkhodja and Landry, 2007). Moreover, scientists who are well connected, i.e. who occupy a central position in professional networks, may leverage social capital to build up higher scientific and technical human capital (Ponomariov and Boardman, 2010). Higher scientific and technical human capital is positively related to higher industry involvement because scientists with a high endowment are assumed to possess greater ability to carry out research projects together with industry. They are more visible and thus more likely to be approached by industry. Moreover, publishing scientists signal the quality of their research which makes them attractive as collaboration partners (Murray, 2004; Link et al., 2007). 
A second element of the model is the environment of the focal entity which may lead to imprinting. In this regard, prior literature has focused on the characteristics of organizations that influence a scientist’s involvement with industry (e.g., Meyer-Krahmer and Schmoch, 1998; Thursby and Thursby, 2002; Siegel et al., 2003; Siegel et al., 2004; Geuna and Nesta, 2006). Several studies have shown that industry involvement depends on the mission and institutional context of public scientists, with differences being particularly pronounced between university-affiliated scientists and those at mission-oriented public research institutes. Schmoch et al. (2000) and Heinze and Kuhlmann (2008) find for Germany that scientists at universities and Max Planck institutes, who are by and large more oriented towards basic research, collaborate less actively with industry than scientists at Fraunhofer institutes, who typically conduct application-oriented research and are dependent on industry funding. Ponomariov (2008) finds a negative correlation between the scientific quality of university units and their industry involvement. Furthermore, Siegel et al. (2004) argue that scientists require an appropriately designed reward and incentive system in order to be more actively involved with industry. The higher the royalty payments to the scientist, the higher the scientist's propensity to collaborate with industry (Thursby and Kemp, 2002; Link and Scott, 2005). Kenney and Goe (2004) find a positive correlation between the encouragement and support of entrepreneurial activities by the institution (social embeddedness) and the corporate involvement by faculty while comparing the engineering and computer science department of the two U.S. universities Berkeley and Stanford. Louis et al. (1989) show a positive effect of university reputation on academics' engagement with industry. Moreover, there is considerable evidence that scientists from different fields exhibit different industry involvement (Meyer-Krahmer and Schmoch, 1998; Heinze and Kuhlmann, 2008).

Besides the university context as an environmental factor that might lead to imprinting, the presence of industry in the academic's environment needs to be considered. Adopting a spatial perspective, prior literature suggests the presence of industry close to the university's location to increase industry involvement (Audretsch and Stephan, 1996; Arundel and Geuna, 2004; Laursen et al., 2011). But also interaction with industry without close proximity may help academics to recognize opportunities for commercialization (Agrawal and Henderson, 2002; Ozgen and Baron, 2007). Moreover, research grants provided by industry lead academics to engage in patenting (Lawson, 
2013), an indication that collaboration partners oriented towards commercialization may influence an academic's attitude towards commercialization and patenting (Owen-Smith and Powell, 2001; Bercovitz and Feldman, 2008).

Finally, the model suggests other entities to be a source of imprinting. In our context, a focal scientist's peers in a broader sense may exert an influence on her or his involvement with industry. These individuals may be workplace peers (e.g., Bercovitz and Feldman, 2008; Kacperczyk, 2013) or early career mentors (e.g., Bercovitz and Feldman, 2008; Azoulay et al., 2009), but they may also be part of a scientist's social environment such as co-authors (e.g., Stuart and Ding, 2006). In the following, we will look in more detail into the theoretical mechanisms that underlie the relationship between peer influence and industry involvement in order to formulate our hypotheses. A particular focus will be on the issue of intersecting imprints through two distinct types of peer effects that prior studies have devoted relatively little empirical attention to. In that sense, our research is intended to complement prior studies and to provide a more complete picture on the role of peer effects in explaining an academic’s involvement with industry.

\subsection{Hypotheses}

\section{Localized and personal peer effects.}

A key concern in prior literature has been the effect that workplace peers exert on an academic's behavior. We follow Bercovitz and Feldman (2008) and refer to it as the localized peer effect to describe the effect that other academics in the department of the focal scientist have on his or her involvement with industry. Organization theory suggests that, based on mimetic and isomorphic processes, an entity adopts another entity's practice by imitating it in the belief that the new practice is beneficial because the other entity succeeds with it (DiMaggio and Powell, 1983; Giuliani et al., 2010). In a similar way, social learning theory argues that individuals follow the behavior of relevant peers if they face uncertainty about norms (Bandura, 1986; Bercovitz and Feldman, 2008). By observing others, individuals draw inferences about the value of certain choices (Sorensen, 2002), expecting that peers will yield similar payoffs from the respective activities (Ellison and Fudenberg, 1993). Moreover, colleagues' behavior provides information of accepted and supported practice 
(Bercovitz and Feldman, 2007) as well as on local "culture" (Louis et al., 1989; Owen-Smith and Powell, 2001). In fact, Louis et al. (1989) show that local norms with regard to a university's commercial orientation play an important role in predicting an academic's commercial activity. If involvement with industry is common among peers, it is perceived by the individual to conform to prevailing norms. Such prevailing norms may in that regard not correspond to the traditional mission of the university in a Mertonian view, characterized typically by the norms of open science, i.e. communalism, universalism, disinterestedness, and organized skepticism (Merton, 1973). The influence of workplace peers thus alters the traditional normative environment that exerts an effect on the decision to become commercially active.

University departments are characterized by both spatial and social proximity. Proximity increases the chances to interact with and consequently to learn from others (Kacperczyk, 2013). Such frequent social interaction will presumably provoke knowledge spillovers that in turn shape an individual's behavior (Stuart and Ding, 2006; Bercovitz and Feldman, 2008). Bercovitz and Feldman (2008) find for two medical schools in the U.S. that the individual's decision to actively engage in technology transfer by disclosing an invention is influenced by the disclosing behavior of their local peers. Kacperczyk (2013) finds that past entrepreneurial activity of university peers positively influences individual rates of entrepreneurship. Hence, in line with previous studies we expect that social and spatial proximity leads scientists to observe their peers' industry orientation and act correspondingly. As a result, we suggest that a scientist's involvement with industry will be higher the more the scientist's department is oriented towards industry.

Hypothesis 1. There is a positive relationship between a scientist's involvement with industry and the extent to which the scientist's department is oriented towards industry.

Another type of peer effect stems from social interaction that is not necessarily localized. Besides workplace peers, a scientist's co-authors and hence personal collaborators can serve as a reference point. Scientists actively choose whom to collaborate with and will select co-authors they respect and trust, also across institutional boundaries. Co-authorship ties are characterized by frequent interaction 
and scientists are consequently more likely to become entrepreneurs if their co-authors became academic entrepreneurs (Stuart and Ding, 2006). Indeed, based on the social proximity, knowledge spills over easily, although this can be moderated by the fact that co-authors are spatially distant. It is therefore likely to observe a personal peer effect that is distinct from a localized peer effect but similar to it in terms of the mechanism that we expect to influence a focal academic's behavior. Thus we expect that a scientist's industry involvement is likely to be influenced by the behavior of co-authors, such that a co-author's industry orientation will increase the likelihood of a scientist engaging with industry.

Hypothesis 2. There is a positive relationship between a scientist's involvement with industry and the extent to which the scientist's co-authors are oriented towards industry.

\section{The moderating role of age.}

Prior literature indicates that industry involvement is likely to vary with the career age of a scientist (Bercovitz and Feldman, 2008; Lawson and Sterzi, 2012). Based on the human capital argument, more experienced researchers are likely to possess a higher ability to carry out research projects with industry. They typically have a larger network of researchers, not only in academia but also in industry, compared to researchers at an early stage in their career. Social capital, in this respect, begets human capital. Since experienced scientists have been active in a particular field for a longer time period, more opportunities have arisen for them to interact with industry researchers. Moreover, they have had more chances to learn from other researchers who have successfully engaged in industry collaboration or they know researchers who switched from science to industry. Time in this regard is necessary to build up relationships. In fact, Haeussler and Colyvas (2011) find for life scientists in the UK and Germany a positive effect of a scientist's age on commercialization activities, including consulting, patenting, and founding of a new business.

Industry involvement, however, contradicts traditional academic norms. Bercovitz and Feldman (2008), for example, show that the probability of disclosing an invention decreases with 
career age for faculty in medical schools in the U.S. They interpret their finding in such a way that younger researchers tend to more readily adopt new technology transfer policies set up by the research institution. Other research finds no effect at all. Ponomariov and Boardman (2010) cannot detect a significant association between career age and the number of publications with industrial collaborators. Overall, prior literature is not unambiguous regarding the effect of a researcher's career age on industry involvement.

However, there are clear indications of the role age plays as a moderator for the two types of peer effects. According to social learning theory, researchers tend to follow the behavior of peers when they face uncertainty (Bandura, 1986; Bercovitz and Feldman, 2008). Uncertainties are particularly high for younger researchers. Moreover, younger researchers are probably more open regarding their research agenda and practice. They still have to find and establish "their" place in the research community, and they learn by observing the research practice of others. If industry involvement is practiced by others they might more readily follow and internalize this practice compared to more experienced researchers. Adoption of specific practices is thus more likely in the training and qualification phase of younger researchers. Bercovitz and Feldman (2008) find that researchers who were exposed to pro-commercialization activities during their training phase (measured by the number of patent applications at the individual's graduate institution during the time of their training) are more likely to adopt this practice in their own career. Azoulay et al. (2009) find early career experiences to have a substantial impact on academics' careers. Thus, we expect that researchers in an early stage of their career are more likely to adopt the practice they are exposed to. We suggest that both the localized and the personal peer effect will have a stronger impact on a scientist's industry involvement the more recent the vintage of the scientist's $\mathrm{PhD}$, suggesting that imprinting takes place in the early stages of a scientist's academic career.

Hypothesis 3. The relationship between the scientist's involvement with industry and the extent to which the scientist's department is oriented towards industry will be moderated by a scientist's career age such that the scientist's industry involvement will increase the lower the career age is. 
Hypothesis 4. The relationship between the scientist's involvement with industry and the extent to which the scientist's co-authors are oriented towards industry will be moderated by a scientist's career age such that the scientist's industry involvement will increase the lower the career age is.

The interaction of peer effects.

We have previously argued that localized and personal peer effects are contemporaneous so that they may intersect in four different ways. On the one hand, they may be aligned in the sense that they both either suggest high or low industry orientation of localized and personal peers. On the other hand, they may not be aligned which leads to a dissonant situation in which the overall effect is ex-ante unclear. Bercovitz and Feldman (2008) find for a situation of dissonance between a scientist's training norms and the norms of local peers that scientists will conform to the localized, rather than to the previous training norms. This finding suggests the scientist's age to play a central role when peer effects interact. In that sense, we expect a differential impact of localized versus personal peer effects on an academic's industry involvement depending on his or her career age. Younger researchers face greater uncertainty about prospects for promotion and tenure (Bercovitz and Feldman, 2008). In addition, they are more dependent on their department, for example in terms of funding because they lack opportunities and knowledge to acquire extramural research grants (Grimpe, 2012). We expect that this pressure to conform typically does not exist in social interaction with the scientist's coauthors, since co-authors are self-chosen and do not necessarily have a say in promotion and tenure decisions. As a result, junior faculty members who face dissonance will be more eager to conform to the local environment. In contrast to this, more senior scientists will be less dependent on their department but will rather orient themselves towards their personal peers. In case of dissonance the effects are thus likely to be the opposite of those for younger scientists. Our final hypothesis hence reads as follows.

Hypothesis 5a. Younger scientists, when faced with a situation in which the localized and personal peer norms are not congruent, will conform to the localized, rather than personal, norms. 
Hypothesis 5b. Senior scientists, when faced with a situation in which the localized and personal peer norms are not congruent, will conform to the personal, rather than localized, norms.

\section{Data and Methods}

\subsection{Data}

To analyze the relationship between peer effects, career age and industry involvement we make use of a unique dataset. In the summer of 2010, the Centre for European Economic Research (ZEW) undertook an online survey of academic researchers working in the field of biotechnology in Germany. The population targeted comprised researchers who worked at either a university or a public research institution and who had published at least one paper in a peer-reviewed journal in the field of biotechnology. Researchers were identified using journal publications from the Science Citation Index Expanded (SCIE) in the field of biotechnology between 2004 and 2008. The comprehensive list of relevant journals was compiled based on the subject categories assigned to each journal. Only authors working at an academic institution located in Germany were considered. If provided, the email addresses were taken from the publications to contact the researchers. Otherwise, the email addresses were collected manually from the internet, which involved a complex search since only the authors and affiliations located in Germany were known for each publication but not the link between them. In total, we approached 3,360 researchers based on the information that they had previously published. However, since email addresses retrieved from publications were up to six years old some researchers had already left academia by the time they were contacted. The real gross sample is thus likely to be much smaller. ${ }^{1}$ In total, 592 persons filled in the questionnaire, a response rate of 18 percent, which is consistent with response rates obtained in recent research by means of internet administered surveys in Germany (e.g., Edler et al., 2011; Grimpe, 2012). Of those 592 responses, 91 observations needed to be dropped because the respondent indicated that he or she had left academia. After observations with missing values in the variables of interest had been dropped, a

${ }^{1}$ The number of delivery failure messages is not informative to determine the "real" gross sample since many academic institutions allow the messages to be forwarded or checked remotely after a scientist had left the institution. In order to increase the response rate, two reminders were sent out after the deadline in intervals of three weeks. 
net sample of 355 researchers remained for the empirical investigation. Paper and affiliation characteristics of the population as well as the gross and net samples are shown in Table 7 in the appendix. No alarming bias with regard to the representativeness of the sample was detected. ${ }^{2}$

The publication data from the SCIE convey information not only about the publication activities of the individual researcher between 2004 and 2008 but also about the departmental publication activities through the mentioned affiliations on a publication. After harmonizing the affiliations we constructed a measure for each institution with the number of publications from 2004 to 2008 by members of this institution (excluding publications of the focal scientist). For universities this measure is on the department level; for public research institutions it is on the institution level. The department's or institution's publication record was then linked to the researcher.

Furthermore, we identified patent applications at the European Patent Office (EPO) in which the researcher is named as the inventor. This allows us to construct a measure for the patenting activities of each researcher. Moreover, we determined the region where the scientist's institution is located to control for the regional environment. To allow for a reasonable size, regions are defined at the district level (NUTS-3) in which the scientist's institution resides plus the immediate neighboring districts. Regional information on the number of biotech and pharmaceutical firms was merged using data from two online databases. ${ }^{3}$

\subsection{Variables}

\section{Dependent variable.}

In order to measure a scientist’s involvement with industry, we follow Bozeman and Gaughan (2007), who construct an industry involvement index based on faculty responses to the question of whether they engaged in different types of industry interaction. In our survey, scientists were asked to indicate interaction with respect to five channels: (a) direct collaboration with industry personnel in a joint research project, (b) performing a service (measuring, analyzing, consulting) or creating a technical

\footnotetext{
${ }^{2}$ We test for deviations between the population and the sample by comparing the distributions of four variables characterizing the publications. The results can be obtained from the authors upon request.

${ }^{3}$ We gathered and combined data from the "Biotechnology Database" provided on biotechnologie.de and from the list of "Biotech Companies in Germany" provided by Dechema e.V. (Society for Chemical Engineering and Biotechnology).
} 
artifact (bacteria, cell cultures) on behalf of a company, (c) out-licensing of research results to industry, (d) joint publication of research results with industry personnel, and (e) informal contacts with industry personnel. The time frame the scientists were asked to refer to was the last 12 months, i.e. from about mid-2009 to mid-2010. We then calculated the frequency (in \%) of each item's occurrence in the sample and used the inverse as a weight for the corresponding item. Subsequently, we multiplied each type of interaction with its weight and summed up the factors to create a weighted industrial involvement index. As a robustness check, we used the total number of different interaction channels without considering their frequency of occurrence in the sample. Considering a broad variety of possible channels of interaction has been argued to complement more one-dimensional measures such as invention disclosure and patenting used in prior work (D'Este and Patel, 2007).

\section{Focus variables.}

Our measure of peer effects relies on co-publications with industry personnel by members of the focal scientist's department (localized peer effect) or by the focal scientist's personal collaborators (personal peer effect). Compared to other measures used in prior literature like disclosure of inventions or academic entrepreneurship (e.g., Stuart and Ding, 2006; Bercovitz and Feldman, 2008) co-publications can be regarded as an equivalent if not better measure of peer effects for three reasons. First, they can easily be observed by peers, a pre-requisite for a peer effect to become apparent (e.g., Bercovitz and Feldman, 2008). Faculty members will usually have a good impression of their peers' publications. New publications are oftentimes broadly announced within a department whereas disclosure, patenting or entrepreneurial activity may be more hidden or more difficult to observe. Second, new publications can be observed at the time they are published while it might take a considerable amount of time until, for example, patents become observable (e.g., Harhoff et al., 2005). Third, another reason for accepting co-publications as a suitable measure is that they occur relatively frequently (e.g., Link et al., 2007), compared for example to entrepreneurial activity. Academic entrepreneurship is, despite the interest it attracts from scholars and policy makers, still a relatively rare phenomenon (e.g., Goel and Grimpe, 2012). As a consequence, peer effects based on relatively rare events may be less reliable than those based on a frequently observed pattern of 
activity. Moreover, co-publications correlate with other types of industry involvement (Grimpe and Fier, 2010); they are objective and relatively easy to obtain for a large sample (Stokes and Hartley, 1989; Katz and Martin, 1997). However, the measure might be inaccurate if authors are listed due to other reasons, e.g. for honorary or funding reasons (Hagstrom, 1965; Katz and Martin, 1997). Despite this limitation, co-authorships have been widely used in the empirical literature, for example to identify collaborators (Zucker et al., 1998), social activity (Stokes and Hartley, 1989) or connectedness between publicly funded scientists and company scientists (Cockburn and Henderson, 1998).

We use three main explanatory variables. The first explanatory variable focuses on the scientist's localized peers and their orientation towards industry. To construct this measure, we identified all publications listed in the SCIE that were affiliated with the scientist's department or institute and published between 2004 and 2008. Publications of the focal scientist were excluded. We then identified those publications that were co-authored with industry personnel (identified by affiliation with a firm) and calculated the share of those publications in the total number of publications by department members. ${ }^{4}$ The second variable is intended to capture personal peer effects. The co-authors' industry orientation is measured by identifying all publications by the scientist's co-authors between 2004 and 2008. Again, we identified those publications with industry personnel and calculated the average share of those publications in the total number of publications for each co-author. Since the dependent variable refers to 2009 and 2010, both explanatory variables based on publication information are lagged. The third variable refers to the scientist's career age to test the moderating role of age for the two types of peer effects. Career age is defined as the number of years since the scientist received his or her $\mathrm{PhD}$. This information is available from the survey. As the variable is skewed, we take the natural logarithm of it.

\footnotetext{
${ }^{4}$ One may argue that a co-author affiliated with a firm could have been a colleague of the academic scientist at the time the paper was written who later switched to industry. However, this is rather unlikely since the period between paper submission and acceptance is relatively short in the field of biotechnology. To check for this possibility, 13 journals were randomly chosen from the list of all relevant journals. For 130 papers published in 2006 and 2007 in these journals the average time lag from submission to publication was only 4.3 months, suggesting this problem to be of minor relevance.
} 


\section{Control variables.}

We control for several factors that have been shown to be relevant in studies explaining scientists' involvement with industry (e.g., Link et al., 2007). In this respect, we control for the scientist's research productivity in terms of the number of papers published in SCIE journals from 2004 to 2008. Productivity and industry involvement are likely to be correlated because more productive scientists are more visible and thus more likely to be approached by industry. Moreover, publishing scientists signal the quality of their research which makes them attractive as collaboration partners (Murray, 2004; Link et al., 2007). We also capture the scientist's own past co-authorship with industry by including the number of the scientist's publications between 2004 and 2008 that are co-authored by industry personnel. ${ }^{5}$ In order to capture both the size and the overall research productivity of the department, we include the number of publications in SCIE journals from 2004 to 2008 that were achieved by scientists affiliated with the department excluding the focal scientist. Similarly, we include the average number of publications by the scientist's co-authors. Moreover, we add data on the scientist's patenting activity and generate a dummy variable indicating whether the scientist had applied for a patent in the period from 2004 to $2008{ }^{6}$ The match between the scientist's and inventor's name is based on a complex search algorithm developed at the Centre for European Economic Research (ZEW).

Another indicator of faculty quality is whether a scientist is tenured, i.e. having an employment contract of indeterminate duration, or not, for which we include a dummy variable. Scientific field effects within biotechnology are controlled for by including dummy variables for the broad scientific field in which the scientist currently works, i.e. the life sciences including biology and medicine, natural sciences such as chemistry, engineering, and other sciences. This classification is based on information given by the researcher in the survey. Moreover, we use a dummy variable to indicate whether the scientist's research is applied (in contrast to basic research), which is taken from the questionnaire to control for the technological opportunities that the research offers. The regressions also control for the scientist's institutional affiliation. We create a dummy variable that takes a value

\footnotetext{
${ }^{5}$ We include the average number and not the share of industry co-authored publications because the correlation between the latter variable and the peer effect variable is 0.88 and therefore unacceptably high.

${ }^{6}$ The year assigned to a patent refers to its priority year.
} 
of one if the scientist works at a research-oriented public research institution such as an institute of the Max Planck Society or the Helmholtz Association. Another dummy takes the value of one if the scientist works at an application-oriented public research institution like an institute of the Fraunhofer Society or the Leibniz Association. University scientists are the largest group in the sample and thus serve as the base category. A few scientists in the sample are affiliated with both a university and a public research institute though. We control for the scientist's gender by using a dummy variable that takes a value of one for female scientists. Several studies in different national contexts find male scientists to be more likely to engage with industry (e.g., Link et al., 2007; Grimpe and Fier, 2010), although other research suggests that these findings may be conditioned by the institutional setting and employment context in which female scientists work (Corley and Gaughan, 2005; Colyvas et al., 2012). To capture the "supply side" of industry-science interaction opportunities, we include the number of biotech and pharmaceutical firms in the region. The idea behind this control variable is that industry-science interaction tends to be localized (Laursen et al., 2011) and that more opportunities for interaction arise the higher the regional activity in this technology field. In this context, the region is defined as the district (NUTS-3) in which the scientist's institution resides plus the immediate neighboring districts.

Finally, our research needs to consider the challenges that arise from identification problems in the analysis of social interaction. Prior research has referred to this challenge as the reflection problem (Manski, 1993, 2000; Bercovitz and Feldman, 2008). If the results are not due to endogenous interaction, i.e. the scientist's behavior varies with the behavior of his or her peers, but due to correlated effects, i.e. scientists behave in the same way simply because they face similar conditions, then the validity of the results becomes questionable. To mitigate the problem that peer effects are in fact driven by unobserved characteristics of the department or the institutional environment and are hence the result of correlated effects, we include a dummy variable indicating whether technology transfer activities are ascribed a high importance in the scientist's area of research. This variable is taken from the survey and may proxy, for example, for a situation in which the administration of the institute puts high emphasis on such activity and thus influences scientist behavior. Moreover, the identification problem is alleviated by using the lagged values of peer behavior (Manski, 2000). 
Correlations between the explanatory variables are fairly low (see Table 8 in the appendix). In addition, the average variance inflation factor (VIF) equals 1.34 . Thus, there is no indication of a multicollinearity problem in the data.

\subsection{Methods}

Our dependent variable is the industry involvement index, which is the weighted sum of the different channels a researcher uses to interact with industry. Thus the variable is a continuous variable subject to left-censoring. It takes a value of 0 , which represents the lower limit, if the researcher is not involved in any of the five channels of industry interaction. The largest value of the variable in the sample is 2.6. Consequently, industry involvement is estimated by applying a tobit model (for details on the model see, for example, Wooldridge, 2007). Since we are interested in interaction effects, it is essential to consider the nonlinearity of the model for the calculation of the marginal effects of the explanatory variables. Marginal effects are hence calculated using the approach suggested by Wiersema and Bowen (2009) and Bowen (2010).

As an alternative dependent variable we use the number of industry involvement channels. The variable takes integer values from 0 , in case of no industry involvement, to 5 , if the researcher is involved in all five types of interaction. Since the variable has an upper limit, a count data model would not be an appropriate estimation method. Instead we use the ordered probit model to take into account the ordinal structure of the variable (Wooldridge, 2007). Moreover, we perform several robustness checks to tackle potential endogeneity and selection issues.

\section{Results}

\subsection{Descriptive results}

Table 1 presents descriptive statistics for the variables used in the analysis for the full sample and a split sample, depending on a researcher's above or below median industry involvement index. On average 7.9 percent of the publications within a department are co-authored with personnel from industry. Departments of scientists with below-median industry involvement exhibit lower shares than departments of scientists with above-median industry involvement activities. However, based on a t- 
test, the difference is not significant. A positive relationship between scientists' industry involvement and joint publications of their co-authors with industry personnel becomes evident on the basis of the mean comparison between the two groups. Scientists with higher industry involvement activities have statistically more often co-authors who have published jointly with industry personnel than scientists with lower industry involvement activities. Moreover, the descriptive results also indicate that a scientist's industry involvement varies with the career age. We find that the mean of the career age of scientists with higher industry involvement is significantly larger than the mean for scientists with less industry involvement. While the descriptive results already indicate partial support for our theoretical reasoning, a multivariate analysis is required to test the hypotheses.

[Table 1 about here]

\subsection{Regression results}

Table 2 shows our main model results. Models 1 and 2 report findings from the tobit regressions, in which the industry involvement index is used as the dependent variable. In the baseline model 1 (without interaction effects) we find that co-author publications with industry exhibit a significantly positive effect on a scientist's industry involvement (personal peer effect) while the effect of the share of publications with industry in the scientist's department is not significant (localized peer effect). Model 1 thus finds initial support for hypothesis 2, but not for hypothesis 1.

Looking at the results in model 2, which incorporates the interaction effects, we find a positive and significant coefficient for the share of publications with industry in the scientist's department (localized peers). Regarding the interaction with the career age of the scientist we find a negative and significant coefficient for the share of joint publications with industry in the scientist's department. However, for a correct interpretation of interacting variables in nonlinear models it is necessary to consider their marginal effects. The marginal effect of the moderating variable age (moderating effect) on the relationship between localized peers and industry involvement is negative and significant almost over the whole range of predicted values for the industry involvement (Figure 1, left part). Only for very small predicted values of the industry involvement index the moderating effect is insignificant. Thus, the relationship between localized peers and industry involvement varies 
with scientist's age which supports hypothesis 3 . With increasing age the industry involvement as a result of peers' orientation decreases. In order to determine the overall effect of localized peers on industry involvement and to examine how age influences the significance of the marginal effects of localized peers, Table 3 shows the marginal effect of localized peers on industry involvement at selected values of the moderating variable age, holding all other variables constant at their sample mean value. For young researchers (low value of age) the marginal effect of localized peers on industry involvement is positive and significant. With increasing age the marginal effect of localized peers on industry involvement decreases. For middle-aged researchers the negative moderating effect of age offsets the positive effect of localized peers. For these researchers localized peers have no effect on industry involvement of the focal scientist. At high values of age, the marginal effect of localized peers is even negative and significant. Thus, hypothesis 1 holds only for young researchers.

Regarding the personal peers, the influence of the moderating variable age on the relationship between personal peers and industry involvement changes the sign over the range of predicted values of the industry involvement index, being positive for low predicted values and negative for high values (Figure 1, right part). However, the moderating effect is almost never significant. Consequently, the effect of personal peers on industry involvement is not moderated by the scientist's age. This result rejects hypothesis 4. The marginal effect of personal peers is independent of the scientist's age and positive and significant for all researchers (Table 3). All researchers are “positively” influenced by the behavior of their personal peers which lends support to hypothesis 2 . The marginal effects are in line with the estimated coefficients since the share of publications with industry by co-authors is positive and significant while the interaction term with career age is insignificant (Table 2). Models 3 and 4 use the number of different involvement channels with industry as the dependent variable and are consequently estimated by ordered probit regressions. All results turn out to be consistent with models 1 and 2 .

[Table 2 about here]

[Figure 1 about here]

[Table 3 about here] 
Moreover, we split the sample at the median career age (14 years) and re-estimate the regressions for the split sample (Table 4). For young scientists both peer effects are positive and significant (model 5). This also applies to the corresponding marginal effects. The average marginal effects of localized peers and personal peers on the expected value of the industry involvement index are 1.160 and 0.819 , respectively. ${ }^{7}$ However, when the marginal effects are compared, it turns out that the localized peer effect is not significantly larger than the personal peer effect. In contrast, for senior scientists only the personal peer effect is positive while the localized peer effect is negative. The results hold when the number of industry involvement channels is used as dependent variable instead of the industry involvement index (Models 7 and 8). These findings back up the results for the role of a scientist's career age. For the younger scientists both peer effects are positive while for the senior scientists the personal peer effect is positive and the localized peer effect is negative. ${ }^{8}$

[Table 4 about here]

To test the final hypothesis 5, we split the scientists into four groups based on high or low industry orientation of their localized and personal peers. To ensure a sufficient high level of industry orientation, we define the industry orientation to be high if the share of joint publications with industry by peers is higher than the mean share plus one standard deviation. This threshold is also used by Bercovitz and Feldman (2008) for the characterization of the local work environment. The largest group of scientists (76 percent) faces a low industry orientation of both their localized and personal peers (Table 5). Three percent of the scientists have localized and personal peers with high industry orientation. In both groups the industry orientation of the scientist's peers are congruent. The two other groups face incongruent peer norms. Eleven percent of the scientists have industry-oriented localized peers and not industry-oriented personal peers while ten percent have not industry-oriented localized peers but industry-oriented personal peers. The distribution of scientists into the four groups is virtually the same for young and senior scientists.

[Table 5 about here]

\footnotetext{
${ }^{7}$ The corresponding marginal effects at sample means are similar (1.210 and 0.854).

${ }^{8}$ The results are robust to different sample splits, e.g. a career age of 10 years. Results are available from the authors upon request.
} 
We generate dummy variables for each group and run the regression for the sample of young and senior scientists, replacing the peer variables by the new dummy variables (Table 6). The group of scientists that have neither industry-oriented localized peers nor industry-oriented personal peers serves as a reference group. ${ }^{9}$ Facing incongruent peer behavior, the industry involvement of young scientists increases if their localized peers are industry-oriented but not their personal peers (Model 9). We find no influence on the industry involvement of young scientists if only the personal peers show industry-oriented behavior. Thus, in case the personal peer behavior does not align with local norms, young researchers are reluctant to adopt these personal peers' behavior. We find different results for senior scientists (Model 10). In case of dissonance, they are responsive to the industry-orientation of personal peers. The coefficient of the dummy variable indicating that only personal peers are industryoriented but not the localized peers is positive and significant. In contrast, if only the localized peers are industry-oriented but the personal peers are not, the industry involvement of senior scientists significantly decreases. Using the number of industry involvement channels rather than the industry involvement index does not change the estimation results (Models 11 and 12).

With regard to aligned peer behavior, we find for young scientists the coefficient of the dummy variable indicating that localized peers as well as personal peers are industry-oriented to be positive and significant. Comparing the size of the effects with a t-test, it turns out that the dummy variable for aligned industry orientation is significantly larger than the variable for the incongruent industry orientation (localized peers are industry-oriented while personal peers are not). Thus, the localized peer effect is reinforced if the personal peers are also industry-oriented. For more experienced scientists, the dummy variable indicating that both types of peers are industry-oriented is insignificant or only marginally significant. In that sense, the contradicting effects of both peer groups seem to be independent of each other and to offset each other.

To summarize, if scientists face incongruent peer behavior, young researchers align their behavior to the prevailing local norms while experienced scientists orient themselves towards their personal peers' behavior. This suggests that the scientist's department acts as dominant reference

\footnotetext{
${ }^{9}$ The interpretation of the following results needs to take into account that the number of observations in all groups but the reference group is relatively low.
} 
point for the scientist's activities in the early years of his or her career. This is likely due to the greater dependence of younger scientists on the department than on co-authors. Hence, our findings lend support for hypotheses $5 \mathrm{a}$ and $5 \mathrm{~b}$.

[Table 6 about here]

Regarding the control variables, we find consistent effects across all models (Table 2). The average marginal effect of career age is positive and significant. Thus, the more recent the vintage of the scientist's $\mathrm{PhD}$ degree, the less likely becomes industry involvement. This applies in particular for the more senior scientists. It appears that the number of publications in the department has no significant effect on industry involvement, i.e. a department's focus on academic research (as opposed to technology development), as evidenced by a high publication output, does not contradict industry involvement. In fact, a focus of the scientist on academic research, measured by the total number of publications, has a positive effect on industry involvement. Thus, our results substantiate prior findings that more productive scientists are more visible and thus signal the quality of their research which makes them attractive as collaboration partners (Murray, 2004; Link et al., 2007). The publication output of co-authors also seems to increase the industry involvement of scientists but only for younger researchers. Prior joint publications with industry by the scientist do not have an effect. Moreover, we find that scientists whose research is application-oriented exhibit higher industry involvement while the type of institution does not have an effect. Biotechnology scientists with a focus on engineering and the natural sciences are more engaged with industry compared to scientists working in the field of life sciences while there are no other significant discipline effects. Existing literature that documents such disciplinary effects is thus confirmed (e.g., Grimpe and Fier, 2010). Prior patent applications of the scientist turn out to have no effect on industry involvement. If the scientist's area of research is characterized by a high importance of technology transfer activities, industry involvement of the scientist is found to be higher. Interestingly, all other control variables seem to be irrelevant for explaining a scientist's involvement with industry. In this respect, we find no effect of tenure or gender. The non-significant effect of gender confirms recent research that does not find significant gender differences in the likelihood to disclose and to successfully commercialize inventions once different outcome measures and a more comprehensive set of control variables is 
used (Colyvas et al., 2012). Moreover, our regional control variable, which is intended to capture the local "pool” of collaboration opportunities, turns out to be insignificant, although prior literature had shown that collaboration patterns tend to be localized (e.g., Laursen et al., 2011).

\subsection{Robustness tests}

We had previously argued that the identification of peer effects is not trivial. This section therefore presents several robustness tests to assess the validity of our findings. A potential selection bias might arise if staff hiring relies on the applicant's former industry involvement so that resulting departmental effects are not driven by the department's influence but are due to the department's hiring strategy. A selection problem might also arise on the part of a researcher if application-oriented researchers switch to departments with a higher degree of industry involvement. We address this issue by comparing previous patenting activities by researchers who were newly hired in the period from 2006 to 2008 between more and less industry-oriented departments. Previous patenting activities are measured as a dummy variable that takes the value of one if a researcher is listed at least once as an inventor on a patent application that was filed before the year in which the researcher took up employment at the current department. More and less industry-oriented departments are distinguished by a sample split at the mean share of the department's joint publications with industry personnel. In this three-year period, 67 researchers were hired. The shares of newly hired researchers with previous patenting activities are 33 percent for less industry-oriented departments and 42 percent for more industry-oriented departments. A Chi2-test confirms that there is no significant difference between the two groups of departments. Thus, we can conclude that the results are not driven by a selection.

In addition, our survey results show that researchers rank publishing as the most important task. 91 percent of the researchers assess publishing as a very important task of researchers; an additional 8 percent rated it as an important task. In contrast to this, commercial activities play only a minor role. Technology transfer is rated by 9 percent (18 percent) of the respondents as a very important (important) task. Patenting activities reach similar values (10 percent very important; 16 percent important). Accordingly, hiring decisions can be assumed to be primarily based on the publication 
record of the applicant, not on his or her prior industry involvement (see also Bercovitz and Feldman, 2007).

Similarly, a potential selection bias might arise from scientists choosing particularly industryoriented co-authors. To address this concern, we refer to the population of potential co-authors, i.e. all scientists listed as authors on all publications that provide the basis for our sampling and test whether scientists with above median industry involvement particularly select co-authors with pronounced industry orientation. For this purpose, we compare the average share of publications with industry by co-authors with the average share of publications with industry by the pool of authors that were not selected (non-co-authors). For scientists with above median industry involvement, the average share of publications with industry by co-authors is 14.6 percent while the average share of publications with industry by non-co-authors is 17.5 percent, i.e. the industry orientation of co-authors is in fact lower than the industry orientation of non-co-authors although the means statistically differ only on a 10 percent significance level. The results lead us to conclude that scientists in our sample with above median industry involvement do not systematically pick those co-authors with the highest industry orientation.

Moreover, scientists might have found their industry-oriented co-authors through prior (presample) involvement with industry. While longitudinal data on all potential interaction channels with industry are hard to obtain, the patenting activity of scientists is one prominent channel that we do observe. If it is true that co-authors with high industry orientation are found through prior involvement with industry in other channels, we should find that scientists with above median industry involvement appear significantly more often as inventors on patents applied for by a commercial firm than scientists with below median industry involvement. Our results based on the patenting activities of the focal scientists up to the year 2003 (since we use publication data for the period 2004 to 2008) show that this is in fact not the case: There is no significant difference in average patenting between the two groups of scientists if we use the entire patenting history up to the year 2003, if we restrict the patenting history to the 10 -year period prior to 2003 , if we look at all scientists, or if we only look at those scientists with a career age of at least five years (on average about one patent in each case where the applicant is a commercial firm). In this regard, while we 
cannot look deeper into the selection mechanism of co-authors, we do not find past (pre-sample) industry involvement through patenting to be significantly higher for those scientists with recent above median industry involvement.

Another potential bias may be due to "reverse-imprinting", i.e. the focal scientist might have actually published together with industry prior to collaborating with co-authors from academia, such that it is effectively the focal scientist who imprints on his or her co-authors. To address this concern, the regression models include the focal scientist's own co-authored publications with industry. Moreover, we re-estimate the models with two samples that were restricted to those scientists who published with industry a minimum of one year (two years) after the scientist's first co-author had published together with industry. It turns out that the effects are robust in both samples and thus unlikely to be affected by reverse-imprinting. ${ }^{10}$

Prior literature has also noted that early career factors may influence an academic's behavior in his or her later career (Bercovitz and Feldman, 2008; Lawson and Sterzi, 2012). Hence, we use information available from the survey on the university from which the focal scientists received their $\mathrm{PhD}$ degree. If the institution is a technical university we assume that it places more emphasis on interaction with industry. The reason for this assumption is that the scientific and educational profile of these universities in Germany is typically characterized by a strong focus on engineering, technical and natural sciences. According to aggregate statistics, technical universities attract much higher external funding from industry than other universities in Germany. ${ }^{11}$ Hence, award and promotion criteria at technical universities are also likely to reflect industry orientation to a higher extent. Consequently, we introduce a dummy variable into the regressions that takes a value of one if the PhD was granted from a technical university. The regressions include an additional dummy variable to control for the fact that for 26 percent of the scientists in the sample no information on the $\mathrm{PhD}$ granting institution was available. It turns out that all results for the main variables remain robust and the dummy variables have no explanatory power. ${ }^{12}$

\footnotetext{
${ }^{10}$ The results are available from the authors upon request.

${ }^{11}$ See https://www.destatis.de/DE/PresseService/Presse/Pressemitteilungen/2012/10/ PD12_358_213.html

${ }^{12}$ The results are available from the authors upon request.
} 
To explore the possibility that more recent industry orientation of peers may be more relevant in influencing a focal academic's behavior, we construct new explanatory variables based on shorter time periods, i.e. from 2005 to 2008 and from 2006 to 2008. The effects remain qualitatively robust even though some coefficients are no longer significant. However, while the initial choice of the period from 2004 to 2008 could be regarded as arbitrary, we would argue that it better suits our study objective than any of the shorter periods of time. Academics are unlikely to base their behavior on casual observation of a singular event. Rather, social learning theory argues that individuals draw inferences about the value of certain choices they observe over time (Sorensen, 2002). This is especially relevant since co-publications with industry personnel are more the exception than the rule (see Table 1). ${ }^{13}$

\section{Discussion and conclusion}

Our study draws a distinction between localized and personal peer effects on academics' involvement with industry to elucidate how two different types of contemporaneous peer effects shape the behavior of scientists in an academic environment. Based on a sample of biotechnology scientists in Germany, we find that a scientist's involvement with industry will increase with the orientation of the scientist's department towards industry, even though this finding appears only to hold for younger scientists. Moreover, we find a scientist's involvement with industry to increase with the industry orientation of his or her co-authors, an effect that holds irrespective of the scientist's career age. Therefore, both types of peer effects apply differently to different groups of scientists. Our research also studies their interaction and specifically a situation in which they are incongruent. We find that the effects of dissonance are different between young and experienced scientists in that younger scientists will revert to the localized norms while senior scientists will orient themselves more towards their personal collaborators. Hence, while imprinting takes place in the early stages of a scientist's academic career, younger scientists are also more likely to orient themselves towards their local environment and align their behavior with the prevailing local norm regarding industry involvement.

\footnotetext{
${ }^{13}$ The results are available from the authors upon request.
} 
We contribute to the literature in several ways. First, we extend existing studies in the field by focusing on a relatively understudied area, namely different contemporaneous peer effects (Marquis and Tilcsik, 2013). Our distinction between the effects that stem from localized and personal peers allows us to examine the relative impact of both as well as their interaction. We identify those scientists that are faced with incongruent social influence and we are able to derive group-specific effects while taking the scientist's career age into account. In that sense, we identify the researcher's career age as an important boundary condition for a researcher's susceptibility to imprinting. Moreover, we extend prior literature on peer effects and industry involvement by considering a wide variety of interactions with industry which has been argued to complement measures like invention disclosure, patenting or academic entrepreneurship used in prior literature (Bozeman and Gaughan, 2007; D'Este and Patel, 2007). In that sense, our research further contributes to the body of literature that studies the factors motivating academics to depart from the norms of open science and to engage with industry (e.g., Link et al., 2007).

Our research, however, needs to acknowledge several limitations. First, our measure for personal peer effects, i.e. the extent to which co-authors of the scientist have published together with industry personnel, could be related to the measure for localized peer effects in case the scientist's coauthors work at the same department, although we generally find a very low correlation between the two measures. This correlation turns out to be slightly higher for younger scientists, as one would expect. Second, our survey data represent a cross-section. Ideally, it would be desirable to follow scientists throughout their career in order to make a better informed analysis of how career age affects imprinting. It would particularly interesting to see how peer effects change over time. However, by adding publication and patent data to the survey data, we can make use of lagged variables to avoid simultaneity of effects. Third, since we do not have information on the age distribution among the members of a department, our results regarding localized peers might be subject to cohort imprinting effects that may arise because scientists might orient their behavior towards colleagues of the same or higher rank (Marquis and Tilcsik, 2013). As a consequence, more senior members of a department may simply have no role model to relate to if the group of tenured faculty in a department is small. However, our regressions control for whether the scientist is tenured. This variable might actually 
capture part of the effect of having relatively few role models to relate to. Fourth, we cannot fully rule out the possibility that the presence of industry personnel in the co-author network may not be endogenous to the academic's industry involvement. This problem might be alleviated by employing lagged variables. As far as possible, our robustness checks also seek to account for this by considering the timing of industry orientation by the scientists and their personal peers and by accounting for early career factors.

Nevertheless, our research offers important insights for science, technology and innovation (STI) policy making. Given that the traditional mission of public science has shifted in recent years from educating students and conducting (basic) research towards becoming more "entrepreneurial" and engaging with industry (Etzkowitz et al., 2000), our research makes it clear that it is not only the personal motivation of the scientist or the organizational infrastructure (for example, whether or not there is a technology transfer office) that matter for industry involvement; it is also the scientist's immediate environment to which he or she refers when deciding to engage with industry. Our research provides new evidence on one particular element of the environment, namely the localized and personal peers with which the focal scientist interacts. We show that peer effects play a substantial role in explaining industry involvement even if we control for several factors that prior research has found to be informative in the discussion of scientist's engagement with industry (e.g., Link and Scott, 2005; Link et al., 2007).

In that regard, our research informs STI policy making that efforts to promote industry involvement should not ignore peer effects. While peer effects themselves may be difficult to influence, policy measures may be targeted primarily at groups of researchers and not (only) individual scientists. This could generate reinforcing effects on an individual scientist's behavior. Moreover, industry involvement has been shown to typically occur in later stages of a scientist's career. If STI policy aims at extending industry-science linkages, it seems pivotal to facilitate industry-science interaction particularly for scientists in their early stage of career. As imprinting has turned out to be more effective in those years, STI policy could specifically target researcher groups with a high share of early-stage researchers. While virtually all major funding bodies employ some form of funding scheme for young scientists, these grants rarely involve a particular emphasis on 
applied work together with industry. At the same time, however, it should be kept in mind that knowledge exchange at an early stage might not unfold its full potential because younger scientists might have accumulated relatively less knowledge that can be used for commercialization compared to more experienced scientists. 


\section{References}

Adams, J.D., 1990. Fundamental Stocks of Knowledge and Productivity Growth. Journal of Political Economy 98, 673-702.

Agrawal, A., Henderson, R., 2002. Putting patents in context: Exploring knowledge transfer from MIT. Management Science 48, 44-60.

Arundel, A., Geuna, A., 2004. Proximity and the Use of Public Science by Innovative European Firms. Economics of Innovation and New Technologies 13, 559-580.

Arvanitis, S., Sydow, N., Woerter, M., 2008. Do specific forms of university-industry knowledge transfer have different impacts on the performance of private enterprises? An empirical analysis based on Swiss data. Journal of Technology Transfer 33, 504-533.

Audretsch, D.B., Stephan, P.E., 1996. Company-Scientist Locational Links: The Case of Biotechnology. American Economic Review 86, 641-652.

Azoulay, P., Liu, C.C., Stuart, T.E., 2009. Social Influence Given (Partially) Deliberate Matching: Career Imprints in the Creation of Academic Entrepreneurs, Harvard University Working Paper, Cambridge.

Bandura, A., 1986. Social foundations of thought and action: A social cognitive theory. Prentice-Hall, Englewood Cliffs, NJ.

Belderbos, R., Carree, M., Lokshin, B., 2004. Cooperative R\&D and firm performance. Research Policy 33, 1477-1492.

Belkhodja, O., Landry, R., 2007. The Triple-Helix Collaboration: Why Do Researchers Collaborate with Industry and the Government? What are the Factors that Influence the Perceived Barriers? Scientometrics 70, 301-332.

Bercovitz, J., Feldman, M., 2007. Academic entrepreneurs and technology transfer: who participates and why?, in: Malerba, F., Brusoni, S. (Eds.), Perspectives on innovation. Cambridge University Press, Cambridge, pp. 381-398.

Bercovitz, J., Feldman, M., 2008. Academic entrepreneurs: Organizational change at the individual level. Organization Science 19, 69-89.

BIOCOM, 2011. The German Biotechnology Sector 2011. biotechnologie.de, Berlin.

Bowen, H.P., 2010. Total, Structural and Secondary Moderating Effects in the Tobit Model and Their Computation Using Stata, Discussion Paper Series, McColl School of Business, Queens University of Charlotte.

Bozeman, B., 2000. Technology transfer and public policy: A review of research and theory. Research Policy 29, 627-655.

Bozeman, B., Corley, E., 2004. Scientists' collaboration strategies: implications for scientific and technical human capital. Research Policy 33, 599-616.

Bozeman, B., Gaughan, M., 2007. Impacts of grants and contracts on academic researchers' interactions with industry. Research Policy 36, 694-707.

Cockburn, I.M., Henderson, R.M., 1998. Absorptive Capacity, Coauthoring Behavior, and the Organization of Research in Drug Discovery. The Journal of Industrial Economics 46, 157-182.

Colyvas, J.A., Snellman, K., Bercovitz, J., Feldman, M., 2012. Disentangling effort and performance: a renewed look at gender differences in commercializing medical school research. Journal of Technology Transfer 37, 478-489.

Corley, E., Gaughan, M., 2005. Scientists' participation in university research centers: What are the gender differences? Journal of Technology Transfer 30, 371-381.

D'Este, P., Patel, P., 2007. University-Industry Linkages in the UK: What Are the Factors Underlying the Variety of Interactions with Industry? Research Policy 36, 1295-1313.

Dasgupta, P., David, P., 1994. Towards a new economics of science. Research Policy 3, 487-521.

DiMaggio, P.J., Powell, W.W., 1983. The iron cage revisited: Institutional isomorphism and collective rationality in organizational fields. American sociological review 48, 147-160. 
Edler, J., Fier, H., Grimpe, C., 2011. International Scientist Mobility and the Locus of Knowledge and Technology Transfer. Resarch Policy 40, 791-805.

Ellison, G., Fudenberg, D., 1993. Rules of thumb for social learning. Journal of Political Economy 101, 612-643.

Etzkowitz, H., Webster, A., Gebhardt, C., Terra, B.R.C., 2000. The future of the university and the university of the future: evolution of ivory tower to entrepreneurial paradigm. Research Policy 29, 313-330.

Geuna, A., Nesta, L.J.J., 2006. University patenting and its effects on academic research: The emerging European evidence. Research Policy 35, 790-807.

Giuliani, E., Morrison, A., Pietrobelli, C., Rabellotti, R., 2010. Who are the researchers that are collaborating with industry? An analysis of the wine sectors in Chile, South Africa and Italy. Research Policy 39, 748-761.

Goel, R.K., Grimpe, C., 2012. Are all academic entrepreneurs created alike? Evidence from Germany. Economics of Innovation and New Technology 21, 247-266.

Grimpe, C., 2012. Extramural Research Grants and Scientists’ Funding Strategies: Beggars Can’t Be Choosers? Resarch Policy 41, 1448-1460.

Grimpe, C., Fier, H., 2010. Informal University Technology Transfer: A Comparison Between the United States and Germany. Journal of Technology Transfer 35, 637-650.

Haeussler, C., Colyvas, J.A., 2011. Breaking the Ivory Tower: Academic Entrepreneurship in the Life Sciences in UK and Germany. Research Policy 40, 41-54.

Hagstrom, W.O., 1965. The scientific community. Basic Books, New York.

Harhoff, D., Hoisl, K., Webb, C., 2005. Analysing European and international patent citations: A set of EPO patent database building blocks, OECD STI Working Paper 2005/9, Paris.

Heinze, T., Kuhlmann, S., 2008. Across institutional boundaries? Research collaboration in German public sector nanoscience. Research Policy 37, 888-899.

Higgins, M.J., Stephan, P.E., Thursby, J.G., 2008. Conveying quality and value in emerging industries: star scientists and the role of learning in biotechnology, NBER Working Paper, Cambridge, MA.

Jaffe, A., 1989. Real Effects of Academic Research. American Economic Review 97, 957-970.

Jensen, R., Thursby, J., Thursby, M., 2010. University-Industry Spillovers, Government Funding, and Industrial Consulting, NBER Working Paper, Cambridge, MA.

Kacperczyk, A.J., 2013. Social Influence and Entrepreneurship: The Effect of University Peers on Entrepreneurial Entry. Organization Science 24, 664-683.

Katz, J.S., Martin, B.R., 1997. What is research collaboration? Research Policy 26, 1-18.

Kenney, M., Goe, W.R., 2004. The role of social embeddedness in professional entrepreneurship: A comparison of electrical engineering and computer science at UC Berkeley and Stanford. Resarch Policy 33, 691-707.

Laursen, K., Reichstein, T., Salter, A., 2011. Exploring the Effect of Geographical Proximity and University Quality on University-Industry Collaboration in the United Kingdom. Regional Studies 45, 507-523.

Lawson, C., 2013. Academic patenting: the importance of industry support. Journal of Technology Transfer 38, 509-535.

Lawson, C., Sterzi, V., 2012. The role of early career factors in academic patenting, LEI \& BRICK Working Paper, Bureau of Research in Innovation, Complexity and Knowledge, Collegio Carlo Alberto 201201, University of Turin.

Link, A.N., Scott, J.T., 2005. Universities as partners in U.S. research joint ventures. Research Policy 34, 385-393.

Link, A.N., Siegel, D.S., Bozeman, B., 2007. An empirical analysis of the propensity of academics to engage in informal university technology transfer. Industrial \& Corporate Change 16, 641-655.

Louis, K.S., Blumenthal, D., Gluck, M.E., Stoto, M.A., 1989. Entrepreneurs in academe: An exploration of behaviors among life scientists. Administrative Science Quaterly 34, 110-131.

Manski, C.F., 1993. Identification of Endogenous Social Effects: The Reflection Problem. Review of Economic Studies 60, 531-542.

Manski, C.F., 2000. Economic Analysis of Social Interactions. Journal of Economic Perspectives 14, 115-136. 
Marquis, C., Tilcsik, A., 2013. Imprinting: Toward a multilevel theory. Academy of Management Annals 7, 193-243.

Merton, R.K., 1973. The Normative Structure of Science, in: Merton, R.K. (Ed.), The Sociology of Science: Theoretical and Empirical Investigations. The University of Chicago Press, Chicago, IL.

Meyer-Krahmer, F., Schmoch, U., 1998. Science-Based Technologies: University-Industry Interactions in Four Fields. Research Policy 27, 835-851.

Murray, F., 2004. The role of academic inventors in entrepreneurial firms: sharing the laboratory life. Research Policy 33, 643-659.

Owen-Smith, J., Powell, W.W., 2001. To Patent or Not: Faculty Decisions and Institutional Success at Technology Transfer. Journal of Technology Transfer 26, 99-114.

Ozgen, E., Baron, R.A., 2007. Social sources of information in opportunity recognition: Effects of mentors, industry networks, and professional forums. Journal of Business Venturing 22, 174192.

Ponomariov, B.L., 2008. Effects Of University Characteristics On Scientists' Interactions With The Private Sector: An Exploratory Assessment. Journal of Technology Transfer 33, 485-503.

Ponomariov, B.L., Boardman, P.C., 2010. Influencing Scientists' Collaboration and Productivity Patterns through New Institutions: University Research Centers and Scientific and Technical Human Capital. Research Policy 39, 613-624.

Schmoch, U., Licht, G., Reinhard, M., 2000. Wissens- und Technologietransfer in Deutschland. Fraunhofer IRB Verlag, Stuttgart.

Siegel, D.S., Waldman, D., Link, A., 2003. Assessing the impact of organizational practices on the relative productivity of university technology transfer offices: an exploratory study. Research Policy 32, 27-48.

Siegel, D.S., Waldman, D.A., Atwater, L.E., Link, A.N., 2004. Toward a model of the effective transfer of scientific knowledge from academicians to practitioners: Qualitative evidence from the commercialization of university technologies. Journal of Engineering and Technology Management 21, 115-142.

Sorensen, A.T., 2002. Social learning in the demand for employer-sponsored health insurance. Johns Hopkins University Press, Baltimore, MD.

Sorensen, O., Audia, P.G., 2000. The social structure of entrepreneurial activity: Geographic concentration of footwear production in the United States, 1940-1989. American Journal of Sociology 106, 424-461.

Sorensen, O., Fleming, F., 2004. Science and the diffusion of knowledge. Research Policy 33, 16151633.

Stokes, T.D., Hartley, J.A., 1989. Coauthorship, Social Structure and Influence Within Specialties. Social Studies of Science 19, 101-125.

Stuart, T.E., Ding, W.W., 2006. When do scientists become entrepreneurs? The social structural antecedents of commercial activity in the academic life sciences. Americal Journal of Sociology 111, 97-144.

Thursby, J.G., Kemp, S., 2002. Growth and productive efficiency of university intellectual property licensing. Research Policy 31, 109-124.

Thursby, J.G., Thursby, M.C., 2002. Who is selling the ivory tower? Sources of growth in university licensing. Management Science 48, 90-104.

Wiersema, M.F., Bowen, H.P., 2009. The use of limited dependent variable techniques in strategy research: issues and methods. Strategic Management Journal 30, 679-692.

Wooldridge, J.M., 2007. Econometric analysis of cross section and panel data, 2. ed, Cambridge, MA.

Zucker, L.G., Darby, M.R., Armstrong, J.S., 2002. Commercializing Knowledge: University Science, Knowledge Capture, and Firm Performance in Biotechnology. Management Science 48, 138153.

Zucker, L.G., Darby, M.R., Brewer, M.B., 1998. Intellectual human capital and the birth of US biotechnology enterprises. American Economic Review 88, 290-306. 


\section{Tables and Figures}

Table 1: Sample descriptives, total and by industry involvement

\begin{tabular}{|c|c|c|c|c|c|c|c|c|c|}
\hline & \multicolumn{4}{|c|}{$\begin{array}{l}\text { All observations } \\
(\mathrm{N}=355)\end{array}$} & \multicolumn{2}{|c|}{$\begin{array}{c}\text { Below median } \\
\text { industry involvement } \\
\text { index }(\mathrm{N}=175)\end{array}$} & \multicolumn{2}{|c|}{$\begin{array}{c}\text { Above median } \\
\text { industry involvement } \\
\text { index }(\mathrm{N}=180)\end{array}$} & \multirow[b]{2}{*}{ Sig. ${ }^{1)}$} \\
\hline & Mean & Std. Dev. & Min & Max & Mean & Std. Dev. & Mean & Std. Dev. & \\
\hline \multicolumn{10}{|l|}{ Dependent variable } \\
\hline Industry involvement index & 0.943 & 0.716 & 0 & 2.617 & 0.325 & 0.270 & 1.544 & 0.454 & $* * *$ \\
\hline No. of industry involvement channels & 2.363 & 1.418 & 0 & 5 & 1.114 & 0.726 & 3.578 & 0.676 & $* * *$ \\
\hline \multicolumn{10}{|l|}{ Focus variable } \\
\hline Joint publications w/ industry by dept. (share) & 0.079 & 0.075 & 0 & 0.500 & 0.076 & 0.065 & 0.083 & 0.084 & \\
\hline Joint publications w/ industry by co-authors (share) & 0.103 & 0.205 & 0 & 1 & 0.059 & 0.160 & 0.146 & 0.233 & $* * *$ \\
\hline Years since $\mathrm{PhD}(\ln )$ & 2.286 & 1.063 & 0 & 3.932 & 2.153 & 1.081 & 2.416 & 1.033 & $* *$ \\
\hline \multicolumn{10}{|l|}{ Control variable } \\
\hline No. of publications by dept. & 51.935 & 50.149 & 0 & 205 & 54.943 & 51.829 & 49.011 & 48.425 & \\
\hline Average no. of publications by co-authors & 2.859 & 1.954 & 0 & 15 & 2.670 & 1.972 & 3.043 & 1.923 & $*$ \\
\hline No. of publications by individual & 3.617 & 4.155 & 1 & 26 & 2.783 & 2.998 & 4.428 & 4.906 & $* * *$ \\
\hline No. of joint publications w/ industry by individual & 0.372 & 0.964 & 0 & 10 & 0.166 & 0.492 & 0.572 & 1.233 & $* * *$ \\
\hline Patent application (d) & 0.265 & 0.442 & 0 & 1 & 0.234 & 0.425 & 0.294 & 0.457 & \\
\hline Applied research orientation (d) & 0.721 & 0.449 & 0 & 1 & 0.589 & 0.494 & 0.850 & 0.358 & $* * *$ \\
\hline Field: life sciences (biology, medicine) (d) & 0.772 & 0.420 & 0 & 1 & 0.829 & 0.378 & 0.717 & 0.452 & $* *$ \\
\hline Field: natural sciences (d) & 0.104 & 0.306 & 0 & 1 & 0.074 & 0.263 & 0.133 & 0.341 & $*$ \\
\hline Field: engineering (d) & 0.059 & 0.236 & 0 & 1 & 0.029 & 0.167 & 0.089 & 0.285 & $* *$ \\
\hline Field: other (d) & 0.065 & 0.247 & 0 & 1 & 0.069 & 0.253 & 0.061 & 0.240 & \\
\hline Universities (d) & 0.645 & 0.479 & 0 & 1 & 0.611 & 0.489 & 0.678 & 0.469 & \\
\hline Research-oriented public research institution (d) & 0.310 & 0.463 & 0 & 1 & 0.377 & 0.486 & 0.244 & 0.431 & $* * *$ \\
\hline Application-oriented public research institution (d) & 0.085 & 0.279 & 0 & 1 & 0.040 & 0.197 & 0.128 & 0.335 & $* * *$ \\
\hline Tenured position (d) & 0.583 & 0.494 & 0 & 1 & 0.543 & 0.500 & 0.622 & 0.486 & \\
\hline Female (d) & 0.273 & 0.446 & 0 & 1 & 0.309 & 0.463 & 0.239 & 0.428 & \\
\hline No. of biotech enterprises in region & 38.355 & 40.075 & 0 & 122 & 43.017 & 41.777 & 33.822 & 37.916 & $* *$ \\
\hline High importance of tech. transfer activities (d) & 0.090 & 0.287 & 0 & 1 & 0.034 & 0.182 & 0.144 & 0.353 & $* * *$ \\
\hline
\end{tabular}

Note: 1$)^{* * *}(* *, *)$ indicates significance level of $1 \%(5 \%, 10 \%)$ of a two-sided t-test on the mean equality between scientists with below and above median industry involvement. For dummy variables, a Chi2-test is applied. 
Table 2: Estimation results

\begin{tabular}{|c|c|c|c|c|}
\hline & $\begin{array}{c}\text { Model } 1 \\
\text { Industry } \\
\text { involvement } \\
\text { index } \\
\end{array}$ & $\begin{array}{c}\text { Model } 2 \\
\text { Industry } \\
\text { involvement } \\
\text { index } \\
\end{array}$ & $\begin{array}{c}\text { Model } 3 \\
\text { No. of industry } \\
\text { involvement } \\
\text { channels }\end{array}$ & $\begin{array}{c}\text { Model } 4 \\
\text { No. of industry } \\
\text { involvement } \\
\text { channels }\end{array}$ \\
\hline Joint publications w/ industry by dept. (share) & $\begin{array}{l}-0.076 \\
(0.417)\end{array}$ & $\begin{array}{c}2.670^{* *} \\
(1.345)\end{array}$ & $\begin{array}{l}-0.028 \\
(0.649)\end{array}$ & $\begin{array}{c}4.556 * * \\
(2.163)\end{array}$ \\
\hline Int.: joint publ. w/ ind. by dept. * years since $\mathrm{PhD}$ & & $\begin{array}{c}-1.165^{* *} \\
(0.509)\end{array}$ & & $\begin{array}{c}-1.942^{* *} \\
(0.821)\end{array}$ \\
\hline Joint publ. w/ industry by co-authors (share) & $\begin{array}{c}0.754 * * * \\
(0.227)\end{array}$ & $\begin{array}{c}1.121 * * * \\
(0.384)\end{array}$ & $\begin{array}{c}1.179 * * * \\
(0.388)\end{array}$ & $\begin{array}{c}1.848 * * * \\
(0.594)\end{array}$ \\
\hline Int.: joint publ. w/ ind. by co-authors * years since $\mathrm{PhD}$ & & $\begin{array}{l}-0.174 \\
(0.121)\end{array}$ & & $\begin{array}{l}-0.305^{*} \\
(0.182)\end{array}$ \\
\hline Years since PhD (ln) & $\begin{array}{c}0.148 * * * \\
(0.044)\end{array}$ & $\begin{array}{c}0.260 * * * \\
(0.056)\end{array}$ & $\begin{array}{c}0.250 * * * \\
(0.069)\end{array}$ & $\begin{array}{c}0.439 * * * \\
(0.087)\end{array}$ \\
\hline No. of publications by dept. & $\begin{array}{l}-0.001 \\
(0.001)\end{array}$ & $\begin{array}{l}-0.001 \\
(0.001)\end{array}$ & $\begin{array}{l}-0.002 \\
(0.001)\end{array}$ & $\begin{array}{l}-0.002 \\
(0.001)\end{array}$ \\
\hline Average no. of publications by co-authors. & $\begin{array}{l}0.040^{*} \\
(0.021)\end{array}$ & $\begin{array}{l}0.040^{*} \\
(0.021)\end{array}$ & $\begin{array}{l}0.070^{* *} \\
(0.034)\end{array}$ & $\begin{array}{l}0.070^{* *} \\
(0.035)\end{array}$ \\
\hline No. of publications by individual & $\begin{array}{c}0.024^{* *} \\
(0.009)\end{array}$ & $\begin{array}{l}0.024^{* *} \\
(0.010)\end{array}$ & $\begin{array}{l}0.037 * * \\
(0.015)\end{array}$ & $\begin{array}{l}0.037 * * \\
(0.015)\end{array}$ \\
\hline No. of publications w/ industry by individual & $\begin{array}{c}0.015 \\
(0.047)\end{array}$ & $\begin{array}{c}0.028 \\
(0.046)\end{array}$ & $\begin{array}{c}0.043 \\
(0.089)\end{array}$ & $\begin{array}{c}0.062 \\
(0.087)\end{array}$ \\
\hline Patent application (d) & $\begin{array}{c}-0.016 \\
(0.077)\end{array}$ & $\begin{array}{c}-0.018 \\
(0.077)\end{array}$ & $\begin{array}{c}-0.035 \\
(0.123)\end{array}$ & $\begin{array}{c}-0.039 \\
(0.124)\end{array}$ \\
\hline Applied research orientation (d) & $\begin{array}{c}0.504^{* * *} \\
(0.073)\end{array}$ & $\begin{array}{c}0.498 * * * \\
(0.071)\end{array}$ & $\begin{array}{c}0.807^{* * * *} \\
(0.129)\end{array}$ & $\begin{array}{c}0.806^{* * *} \\
(0.130)\end{array}$ \\
\hline Field: natural sciences (d) & $\begin{array}{l}0.174^{*} \\
(0.095)\end{array}$ & $\begin{array}{l}0.173 * \\
(0.095)\end{array}$ & $\begin{array}{c}0.256 \\
(0.168)\end{array}$ & $\begin{array}{c}0.255 \\
(0.169)\end{array}$ \\
\hline Field: engineering (d) & $\begin{array}{l}0.289 * \\
(0.152)\end{array}$ & $\begin{array}{c}0.303^{* *} \\
(0.148)\end{array}$ & $\begin{array}{c}0.503^{* *} \\
(0.248)\end{array}$ & $\begin{array}{c}0.536^{* *} \\
(0.244)\end{array}$ \\
\hline Field: other (d) & $\begin{array}{c}0.011 \\
(0.120)\end{array}$ & $\begin{array}{c}0.021 \\
(0.119)\end{array}$ & $\begin{array}{c}0.055 \\
(0.188)\end{array}$ & $\begin{array}{c}0.075 \\
(0.188)\end{array}$ \\
\hline Research-oriented public research institution (d) & $\begin{array}{l}-0.094 \\
(0.093)\end{array}$ & $\begin{array}{l}-0.079 \\
(0.090)\end{array}$ & $\begin{array}{l}-0.141 \\
(0.147)\end{array}$ & $\begin{array}{l}-0.116 \\
(0.145)\end{array}$ \\
\hline Application-oriented public research institution (d) & $\begin{array}{c}0.180 \\
(0.128)\end{array}$ & $\begin{array}{c}0.181 \\
(0.129)\end{array}$ & $\begin{array}{c}0.289 \\
(0.200)\end{array}$ & $\begin{array}{c}0.294 \\
(0.205)\end{array}$ \\
\hline Tenured position (d) & $\begin{array}{l}-0.029 \\
(0.091)\end{array}$ & $\begin{array}{l}-0.036 \\
(0.088)\end{array}$ & $\begin{array}{l}-0.059 \\
(0.145)\end{array}$ & $\begin{array}{l}-0.071 \\
(0.141)\end{array}$ \\
\hline Female (d) & $\begin{array}{l}-0.089 \\
(0.079)\end{array}$ & $\begin{array}{l}-0.072 \\
(0.078)\end{array}$ & $\begin{array}{c}-0.15 \\
(0.123)\end{array}$ & $\begin{array}{l}-0.123 \\
(0.122)\end{array}$ \\
\hline No. of biotech enterprises in region & $\begin{array}{c}-0.001 \\
(0.001)\end{array}$ & $\begin{array}{c}-0.001 \\
(0.001)\end{array}$ & $\begin{array}{l}-0.001 \\
(0.001)\end{array}$ & $\begin{array}{c}-0.001 \\
(0.001)\end{array}$ \\
\hline High importance of tech. transfer activities (d) & $\begin{array}{c}0.395 * * * \\
(0.126)\end{array}$ & $\begin{array}{c}0.379 * * * \\
(0.123)\end{array}$ & $\begin{array}{c}0.624 * * * \\
(0.206)\end{array}$ & $\begin{array}{c}0.608^{* * *} \\
(0.203)\end{array}$ \\
\hline Constant & $\begin{array}{l}-0.033 \\
(0.149) \\
\end{array}$ & $\begin{array}{l}-0.287 \\
(0.179) \\
\end{array}$ & & \\
\hline Pseudo R2 & 0.16 & 0.17 & 0.11 & 0.12 \\
\hline $\mathrm{N}$ & 355 & 355 & 355 & 355 \\
\hline Wald F/chi2 & 12.94 & 12.61 & 192.92 & 216.42 \\
\hline P-value & 0.000 & 0.000 & 0.000 & 0.000 \\
\hline Log likelihood & -350.102 & -346.369 & -531.664 & -527.580 \\
\hline
\end{tabular}

Notes: Coefficients are shown (standard errors clustered by university/public research institution in parentheses). *** $(* *, *)$ indicates a significance level of $1 \%(5 \%, 10 \%)$. (d): dummy variable. Reference categories: life sciences (biology, medicine); university affiliation. 
Figure 1: Moderating effect of age on the relationship between localized/personal peers and the predicted value of the industry involvement index (iii)

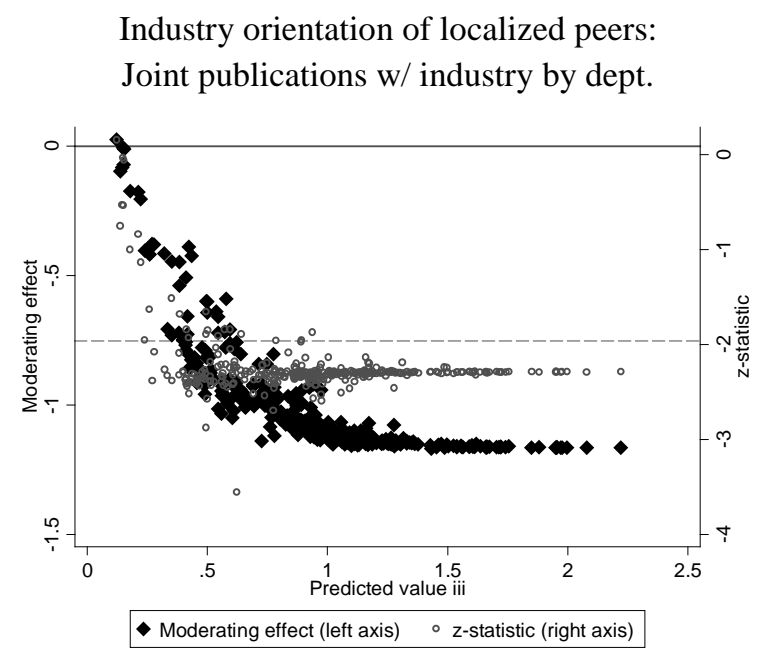

Industry orientation of personal peers: Joint publications w/ industry by co-authors

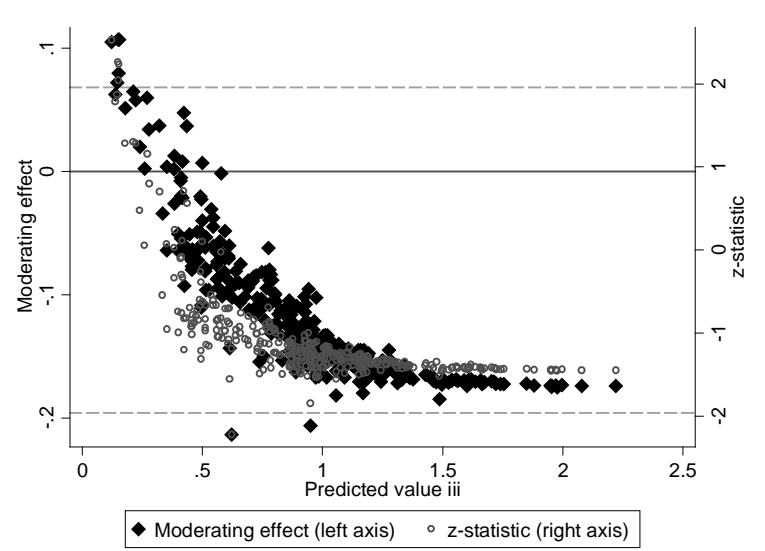

Notes: The grey, dashed line refers to a z-statistic of (-)1.96 (significance level of 5\%). Moderating effect = marginal effect of the moderating variable.

Table 3: Effect of age on the marginal effect of localized/personal effect on the predicted value of the industry involvement index (iii)

\begin{tabular}{lcc}
$\begin{array}{l}\text { Value of } \\
\text { moderating } \\
\text { variable age }\end{array}$ & $\begin{array}{c}\text { Marginal Effect of localized peers } \\
\text { (Joint publications w/ industry by dept.) }\end{array}$ & $\begin{array}{c}\text { Marginal Effect of personal peers } \\
\text { (Joint publications w/ industry by co-authors) }\end{array}$ \\
\hline Low & $1.084^{*}$ & $0.764^{* * *}$ \\
Mean & $0.005^{* *}$ & $0.6655^{* *}$ \\
High & $-1.176^{*}$ & $0.519^{*}$ \\
\hline
\end{tabular}

Note: 1) Below and high value of age is one standard deviation below and above the mean value. All other variables are held constant at their sample mean value. 
Table 4: Estimation results for sub-samples

\begin{tabular}{|c|c|c|c|c|}
\hline & \multirow{2}{*}{\multicolumn{2}{|c|}{$\begin{array}{cc}\text { Model } 5 & \text { Model } 6 \\
\text { Industry involvement index }\end{array}$}} & \multirow{2}{*}{\multicolumn{2}{|c|}{$\begin{array}{c}\text { Model } 7 \quad \text { Model } 8 \\
\begin{array}{c}\text { No. of industry involvement } \\
\text { channels }\end{array}\end{array}$}} \\
\hline & & & & \\
\hline & $\begin{array}{l}\text { Below median } \\
\text { career age }\end{array}$ & $\begin{array}{l}\text { Above median } \\
\text { career age }\end{array}$ & $\begin{array}{l}\text { Below median } \\
\text { career age }\end{array}$ & $\begin{array}{c}\text { Above median } \\
\text { career age }\end{array}$ \\
\hline Joint publications w/ industry by dept. (share) & $\begin{array}{c}1.402^{* *} \\
(0.635)\end{array}$ & $\begin{array}{c}-1.257 * * \\
(0.549)\end{array}$ & $\begin{array}{c}2.438^{* *} \\
(1.062)\end{array}$ & $\begin{array}{c}-2.085^{* *} \\
(0.954)\end{array}$ \\
\hline Joint publications w/ industry by co-authors (share) & $\begin{array}{c}0.989 * * * \\
(0.335)\end{array}$ & $\begin{array}{c}0.542 * * * \\
(0.207)\end{array}$ & $\begin{array}{c}1.627 * * * \\
(0.539)\end{array}$ & $\begin{array}{c}0.879 * * \\
(0.414)\end{array}$ \\
\hline Years since $\mathrm{PhD}(\ln )$ & $\begin{array}{c}0.092 \\
(0.062)\end{array}$ & $\begin{array}{c}0.412 * * \\
(0.169)\end{array}$ & $\begin{array}{l}0.173^{*} \\
(0.095)\end{array}$ & $\begin{array}{c}0.762 * * * \\
(0.294)\end{array}$ \\
\hline No. of publications by dept. & $\begin{array}{c}0.000 \\
(0.001)\end{array}$ & $\begin{array}{l}-0.001 \\
(0.001)\end{array}$ & $\begin{array}{l}-0.000 \\
(0.002)\end{array}$ & $\begin{array}{l}-0.003^{*} \\
(0.002)\end{array}$ \\
\hline Average no. of publications by co-authors & $\begin{array}{l}0.054^{*} \\
(0.028)\end{array}$ & $\begin{array}{c}0.008 \\
(0.023)\end{array}$ & $\begin{array}{c}0.086^{* *} \\
(0.043)\end{array}$ & $\begin{array}{c}0.021 \\
(0.040)\end{array}$ \\
\hline No. of publications by individual & $\begin{array}{c}0.000 \\
(0.021)\end{array}$ & $\begin{array}{c}0.032^{* * *} \\
(0.010)\end{array}$ & $\begin{array}{c}0.009 \\
(0.033)\end{array}$ & $\begin{array}{c}0.052^{* * *} \\
(0.017)\end{array}$ \\
\hline No. of publications w/ industry by individual & $\begin{array}{l}-0.001 \\
(0.093)\end{array}$ & $\begin{array}{c}0.027 \\
(0.049)\end{array}$ & $\begin{array}{c}0.008 \\
(0.142)\end{array}$ & $\begin{array}{c}0.067 \\
(0.118)\end{array}$ \\
\hline Patent application (d) & $\begin{array}{l}-0.050 \\
(0.118)\end{array}$ & $\begin{array}{c}0.035 \\
(0.099)\end{array}$ & $\begin{array}{l}-0.090 \\
(0.184)\end{array}$ & $\begin{array}{c}0.061 \\
(0.171)\end{array}$ \\
\hline Applied research orientation (d) & $\begin{array}{c}0.349 * * * \\
(0.134)\end{array}$ & $\begin{array}{c}0.632 * * * \\
(0.098)\end{array}$ & $\begin{array}{c}0.539 * * \\
(0.224)\end{array}$ & $\begin{array}{c}1.154 * * * \\
(0.192)\end{array}$ \\
\hline Field: natural sciences (d) & $\begin{array}{c}0.008 \\
(0.153)\end{array}$ & $\begin{array}{c}0.300^{* *} \\
(0.128)\end{array}$ & $\begin{array}{c}0.021 \\
(0.244)\end{array}$ & $\begin{array}{l}0.497 * \\
(0.258)\end{array}$ \\
\hline Field: engineering (d) & $\begin{array}{c}0.119 \\
(0.217)\end{array}$ & $\begin{array}{c}0.505^{* *} \\
(0.206)\end{array}$ & $\begin{array}{c}0.255 \\
(0.351)\end{array}$ & $\begin{array}{c}0.923^{* *} \\
(0.359)\end{array}$ \\
\hline Field: other (d) & $\begin{array}{c}0.008 \\
(0.217)\end{array}$ & $\begin{array}{c}0.122 \\
(0.174)\end{array}$ & $\begin{array}{l}-0.036 \\
(0.340)\end{array}$ & $\begin{array}{c}0.359 \\
(0.336)\end{array}$ \\
\hline Research-oriented public research institution (d) & $\begin{array}{l}-0.040 \\
(0.159)\end{array}$ & $\begin{array}{l}-0.167 \\
(0.104)\end{array}$ & $\begin{array}{l}-0.071 \\
(0.253)\end{array}$ & $\begin{array}{l}-0.274 \\
(0.176)\end{array}$ \\
\hline Application-oriented public research institution (d) & $\begin{array}{c}0.040 \\
(0.272)\end{array}$ & $\begin{array}{l}0.235^{*} \\
(0.138)\end{array}$ & $\begin{array}{c}0.040 \\
(0.423)\end{array}$ & $\begin{array}{l}0.447^{*} \\
(0.245)\end{array}$ \\
\hline Tenured position (d) & $\begin{array}{c}0.028 \\
(0.121)\end{array}$ & $\begin{array}{c}-0.273^{*} \\
(0.148)\end{array}$ & $\begin{array}{l}-0.010 \\
(0.187)\end{array}$ & $\begin{array}{l}-0.380 \\
(0.263)\end{array}$ \\
\hline Female (d) & $\begin{array}{l}-0.103 \\
(0.109)\end{array}$ & $\begin{array}{c}0.021 \\
(0.104)\end{array}$ & $\begin{array}{l}-0.145 \\
(0.168)\end{array}$ & $\begin{array}{l}-0.023 \\
(0.174)\end{array}$ \\
\hline No. of biotech enterprises in region & $\begin{array}{l}-0.002 \\
(0.001)\end{array}$ & $\begin{array}{c}0.000 \\
(0.001)\end{array}$ & $\begin{array}{l}-0.002 \\
(0.002)\end{array}$ & $\begin{array}{c}0.001 \\
(0.002)\end{array}$ \\
\hline High importance of tech. transfer activities (d) & $\begin{array}{c}0.416^{* * *} \\
(0.150)\end{array}$ & $\begin{array}{c}0.280 \\
(0.210)\end{array}$ & $\begin{array}{c}0.645^{* * *} \\
(0.248)\end{array}$ & $\begin{array}{c}0.494 \\
(0.391)\end{array}$ \\
\hline Constant & $\begin{array}{c}0.039 \\
(0.211) \\
\end{array}$ & $\begin{array}{l}-0.571 \\
(0.490)\end{array}$ & & \\
\hline Pseudo R2 & 0.13 & 0.21 & 0.10 & 0.15 \\
\hline $\mathrm{N}$ & 167 & 188 & 167 & 188 \\
\hline Wald F/chi2 & 4.92 & 11.80 & 66.39 & 142.83 \\
\hline P-value & 0.000 & 0.000 & 0.000 & 0.000 \\
\hline Log likelihood & -165.006 & -169.999 & -250.888 & -264.473 \\
\hline
\end{tabular}

Notes: Coefficients are shown (standard errors clustered by university/public research institution in parentheses). $* * *(* *, *)$ indicates a significance level of $1 \%(5 \%, 10 \%)$. (d): dummy variable. Reference categories: life sciences (biology, medicine); university affiliation. 
Table 5: Alignment between peer behaviors

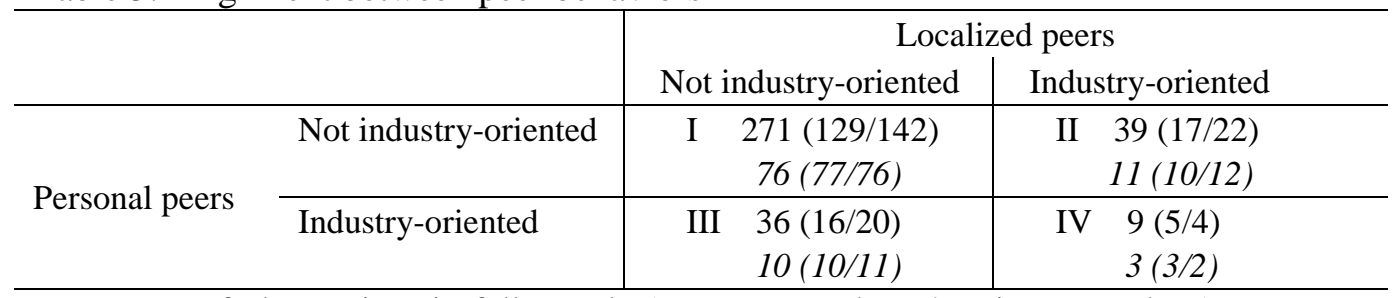

Notes: No. of observations in full sample (young researchers / senior researchers); percentage of observations in italics. 
Table 6: Estimation results with intersecting peer effects behavior for sub-samples

\begin{tabular}{|c|c|c|c|c|}
\hline & Model 9 & Model 10 & Model 11 & Model 12 \\
\hline & \multicolumn{2}{|c|}{ Industry involvement index } & \multicolumn{2}{|c|}{$\begin{array}{c}\text { No. of industry involvement } \\
\text { channels }\end{array}$} \\
\hline & $\begin{array}{c}\text { Below median } \\
\text { career age }\end{array}$ & $\begin{array}{c}\text { Above median } \\
\text { career age }\end{array}$ & $\begin{array}{c}\text { Below median } \\
\text { career age }\end{array}$ & $\begin{array}{c}\text { Above median } \\
\text { career age }\end{array}$ \\
\hline Localized ind.-oriented/personal not ind.-oriented & $\begin{array}{c}0.367 * * \\
(0.164)\end{array}$ & $\begin{array}{c}-0.381^{* * *} \\
(0.130)\end{array}$ & $\begin{array}{c}0.619 * * \\
(0.264)\end{array}$ & $\begin{array}{c}-0.631 * * * \\
(0.240)\end{array}$ \\
\hline Localized not ind.-oriented/personal ind.-oriented & $\begin{array}{c}0.199 \\
(0.231)\end{array}$ & $\begin{array}{l}0.415^{* * * *} \\
(0.122)\end{array}$ & $\begin{array}{c}0.392 \\
(0.366)\end{array}$ & $\begin{array}{c}0.735^{* * *} \\
(0.247)\end{array}$ \\
\hline Localized and personal peers industry-oriented & $\begin{array}{l}0.872 * * \\
(0.371)\end{array}$ & $\begin{array}{l}-0.119 \\
(0.202)\end{array}$ & $\begin{array}{l}1.453 * * \\
(0.592)\end{array}$ & $\begin{array}{r}-0.537 * \\
(0.283)\end{array}$ \\
\hline Years since $\mathrm{PhD}(\mathrm{ln})$ & $\begin{array}{c}0.081 \\
(0.064)\end{array}$ & $\begin{array}{c}0.450 * * * \\
(0.168)\end{array}$ & $\begin{array}{c}0.154 \\
(0.097)\end{array}$ & $\begin{array}{c}0.853 * * * \\
(0.296)\end{array}$ \\
\hline No. of publications by dept. & $\begin{array}{c}0.000 \\
(0.001)\end{array}$ & $\begin{array}{l}-0.002 * \\
(0.001)\end{array}$ & $\begin{array}{c}0.000 \\
(0.002)\end{array}$ & $\begin{array}{l}-0.005^{* *} \\
(0.002)\end{array}$ \\
\hline Average no. of publications by co-authors & $\begin{array}{c}0.057 * * \\
(0.028)\end{array}$ & $\begin{array}{c}0.012 \\
(0.024)\end{array}$ & $\begin{array}{l}0.091 * * \\
(0.043)\end{array}$ & $\begin{array}{c}0.032 \\
(0.042)\end{array}$ \\
\hline No. of publications by individual & $\begin{array}{l}-0.003 \\
(0.021)\end{array}$ & $\begin{array}{c}0.032 * * * \\
(0.009)\end{array}$ & $\begin{array}{c}0.005 \\
(0.033)\end{array}$ & $\begin{array}{c}0.052 * * * \\
(0.016)\end{array}$ \\
\hline No. of publications w/ industry by individual & $\begin{array}{c}0.092 \\
(0.088)\end{array}$ & $\begin{array}{c}0.007 \\
(0.050)\end{array}$ & $\begin{array}{c}0.141 \\
(0.131)\end{array}$ & $\begin{array}{c}0.037 \\
(0.115)\end{array}$ \\
\hline Patent application (d) & $\begin{array}{c}-0.092 \\
(0.118)\end{array}$ & $\begin{array}{c}0.039 \\
(0.098)\end{array}$ & $\begin{array}{c}-0.154 \\
(0.184)\end{array}$ & $\begin{array}{c}0.075 \\
(0.174)\end{array}$ \\
\hline Applied research orientation (d) & $\begin{array}{c}0.350 * * * \\
(0.130)\end{array}$ & $\begin{array}{c}0.637 * * * \\
(0.098)\end{array}$ & $\begin{array}{c}0.539 * * \\
(0.217)\end{array}$ & $\begin{array}{c}1.193^{* * *} \\
(0.193)\end{array}$ \\
\hline Field: natural sciences (d) & $\begin{array}{l}-0.011 \\
(0.152)\end{array}$ & $\begin{array}{c}0.329 * * * \\
(0.125)\end{array}$ & $\begin{array}{c}-0.018 \\
(0.241)\end{array}$ & $\begin{array}{c}0.572 * * \\
(0.243)\end{array}$ \\
\hline Field: engineering (d) & $\begin{array}{c}0.141 \\
(0.227)\end{array}$ & $\begin{array}{c}0.463 * * \\
(0.192)\end{array}$ & $\begin{array}{c}0.290 \\
(0.367)\end{array}$ & $\begin{array}{c}0.847 * * \\
(0.339)\end{array}$ \\
\hline Field: other (d) & $\begin{array}{c}-0.073 \\
(0.222)\end{array}$ & $\begin{array}{c}0.064 \\
(0.176)\end{array}$ & $\begin{array}{c}-0.162 \\
(0.341)\end{array}$ & $\begin{array}{c}0.274 \\
(0.342)\end{array}$ \\
\hline Research-oriented public research institution (d) & $\begin{array}{c}-0.073 \\
(0.157)\end{array}$ & $\begin{array}{l}-0.152 \\
(0.099)\end{array}$ & $\begin{array}{l}-0.126 \\
(0.249)\end{array}$ & $\begin{array}{l}-0.252 \\
(0.167)\end{array}$ \\
\hline Application-oriented public research institution (d) & $\begin{array}{c}0.001 \\
(0.291)\end{array}$ & $\begin{array}{c}0.177 \\
(0.131)\end{array}$ & $\begin{array}{c}-0.035 \\
(0.447)\end{array}$ & $\begin{array}{c}0.332 \\
(0.233)\end{array}$ \\
\hline Tenured position (d) & $\begin{array}{c}0.034 \\
(0.127)\end{array}$ & $\begin{array}{c}-0.263 * \\
(0.152)\end{array}$ & $\begin{array}{c}0.007 \\
(0.200)\end{array}$ & $\begin{array}{l}-0.397 \\
(0.271)\end{array}$ \\
\hline Female (d) & $\begin{array}{c}-0.098 \\
(0.110)\end{array}$ & $\begin{array}{c}0.015 \\
(0.108)\end{array}$ & $\begin{array}{c}-0.140 \\
(0.170)\end{array}$ & $\begin{array}{c}-0.002 \\
(0.183)\end{array}$ \\
\hline No. of biotech enterprises in region & $\begin{array}{l}-0.002 \\
(0.001)\end{array}$ & $\begin{array}{c}0.000 \\
(0.001)\end{array}$ & $\begin{array}{l}-0.002 \\
(0.002)\end{array}$ & $\begin{array}{c}0.000 \\
(0.002)\end{array}$ \\
\hline High importance of tech. transfer activities (d) & $\begin{array}{c}0.325 * * \\
(0.161)\end{array}$ & $\begin{array}{l}0.362 * \\
(0.207)\end{array}$ & $\begin{array}{l}0.499 * \\
(0.266)\end{array}$ & $\begin{array}{l}0.668 * \\
(0.391)\end{array}$ \\
\hline Constant & $\begin{array}{c}0.166 \\
(0.204) \\
\end{array}$ & $\begin{array}{c}-0.697 \\
(0.492)\end{array}$ & & \\
\hline Pseudo R2 & 0.13 & 0.23 & 0.09 & 0.16 \\
\hline $\mathrm{N}$ & 167 & 188 & 167 & 188 \\
\hline Wald F/chi2 & 3.64 & 20.17 & 59.48 & 174.16 \\
\hline P-value & 0.000 & 0.000 & 0.000 & 0.000 \\
\hline Log likelihood & -166.185 & -167.499 & -252.090 & -261.632 \\
\hline
\end{tabular}




\section{Appendix}

Table 7: Representativeness of the sample

\begin{tabular}{lrrr}
\hline & Gross & $\begin{array}{r}\text { Net } \\
\text { sample }\end{array}$ \\
\hline Basis: number of unique papers & 6,990 & 5,635 & 1,140 \\
\hline Number of different authors affiliated w/ institution located in Germany (total) & $18,715^{\text {a) }}$ & 3,360 & 355 \\
Number of authors per paper (mean) & 5.4 & 5.4 & 6.0 \\
Journal quality: impact factor (mean) & 3.6 & 3.6 & 3.7 \\
Number of affiliations located in Germany per paper (mean) & 1.7 & 1.8 & 2.0 \\
Affiliations: Type of institutions (in \%): & & & \\
university & 47.7 & 49.7 & 48.6 \\
public research institution & 26.9 & 27.5 & 32.9 \\
clinic/hospital & 15.3 & 14.5 & 12.8 \\
industry & 10.0 & 8.2 & 5.7 \\
private person & 0.1 & 0.1 & 0.0 \\
Sum & 100.0 & 100.0 & 100.0 \\
\hline
\end{tabular}

Note: a) approximated 
Table 8: Correlation table ( $\mathrm{N}=355)$

\begin{tabular}{|c|c|c|c|c|c|c|c|c|c|c|c|c|c|c|c|c|c|}
\hline Variable & $(1)$ & (2) & (3) & (4) & (5) & (6) & $(7)$ & $(8)$ & $(9)$ & $(10)$ & $(11)$ & $(12)$ & $(13)$ & (14) & $(15)$ & $(16)$ & $(17)$ \\
\hline (1) Joint publications w/ industry by dept. (share) & 1 & & & & & & & & & & & & & & & & \\
\hline Joint publications w/ industry by co-authors (share) & 0.06 & 1 & & & & & & & & & & & & & & & \\
\hline Years since $\mathrm{PhD}(\ln )$ & 0.05 & 0.02 & 1 & & & & & & & & & & & & & & \\
\hline No. of publications by dept. & 0.05 & 0.04 & 0.00 & 1 & & & & & & & & & & & & & \\
\hline Average no. of publications by co-authors & 0.05 & 0.01 & -0.17 & 0.21 & 1 & & & & & & & & & & & & \\
\hline No. of publications by individual & 0.10 & 0.10 & 0.20 & 0.08 & 0.15 & 1 & & & & & & & & & & & \\
\hline No. of publications w/ industry by individual & 0.07 & 0.63 & 0.05 & 0.10 & 0.06 & 0.43 & 1 & & & & & & & & & & \\
\hline (8) Patent application (d) & 0.00 & 0.09 & 0.12 & 0.03 & -0.07 & 0.21 & 0.23 & 1 & & & & & & & & & \\
\hline (9) Applied research orientation (d) & 0.11 & 0.03 & 0.05 & 0.03 & 0.07 & 0.10 & 0.10 & 0.15 & 1 & & & & & & & & \\
\hline (10) Field: natural sciences (d) & -0.01 & 0.03 & 0.04 & -0.12 & 0.02 & -0.02 & 0.01 & -0.02 & -0.06 & 1 & & & & & & & \\
\hline (11) Field: engineering (d) & -0.05 & -0.04 & -0.12 & -0.11 & 0.04 & 0.04 & -0.01 & -0.02 & 0.10 & -0.09 & 1 & & & & & & \\
\hline (12) Field: other (d) & 0.08 & -0.03 & -0.07 & -0.09 & 0.03 & 0.14 & 0.05 & 0.00 & 0.11 & -0.09 & -0.07 & 1 & & & & & \\
\hline (13) Research-oriented public research institution (d) & -0.05 & -0.08 & -0.08 & 0.36 & 0.09 & 0.06 & -0.10 & 0.00 & -0.09 & -0.01 & -0.04 & -0.08 & 1 & & & & \\
\hline (14) Application-oriented public research institution (d) & 0.02 & 0.03 & 0.06 & -0.18 & -0.02 & 0.02 & 0.07 & 0.07 & 0.05 & 0.00 & -0.03 & 0.00 & -0.18 & 1 & & & \\
\hline (15) Tenured position (d) & 0.00 & 0.03 & 0.54 & -0.05 & -0.12 & 0.20 & 0.04 & 0.07 & 0.02 & 0.03 & -0.08 & -0.01 & -0.01 & 0.09 & 1 & & \\
\hline (16) Female (d) & -0.05 & -0.03 & -0.15 & -0.02 & 0.06 & -0.19 & -0.07 & -0.01 & 0.01 & 0.04 & 0.01 & -0.01 & -0.03 & -0.07 & -0.12 & 1 & \\
\hline (17) No. of biotech enterprises in region & 0.02 & -0.02 & 0.02 & 0.40 & -0.03 & -0.04 & -0.03 & -0.07 & -0.04 & -0.07 & -0.09 & -0.06 & 0.15 & 0.05 & 0.00 & 0.03 & 1 \\
\hline (18) High importance of tech. transfer activities (d) & -0.06 & 0.02 & -0.05 & -0.01 & 0.06 & -0.04 & 0.03 & 0.03 & 0.13 & 0.12 & 0.25 & 0.04 & -0.06 & 0.29 & 0.01 & 0.01 & 0.05 \\
\hline
\end{tabular}

